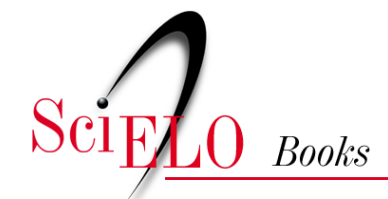

\title{
9 - Na saúde pública In the public health arena
}

\author{
Simone Petraglia Kropf \\ Aline Lopes de Lacerda
}

Diane Grosklaus Whitty (trad.)

\section{SciELO Books / SciELO Livros / SciELO Libros}

KROPF, S.P., and LACERDA, A.L. Na saúde pública = In the public health arena. In: Carlos Chagas, um cientista do Brasil = Carlos Chagas, scientist of Brazil [online]. Translated by Diane Grosklaus Whitty. Rio de Janeiro: Editora FIOCRUZ, 2009, pp. 202-245. ISBN: 978-65-5708-000-9. https://doi.org/10.7476/9786557080009.0013.

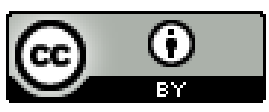

All the contents of this work, except where otherwise noted, is licensed under a Creative Commons Attribution 4.0 International license.

Todo o conteúdo deste trabalho, exceto quando houver ressalva, é publicado sob a licença Creative Commons Atribição 4.0. 

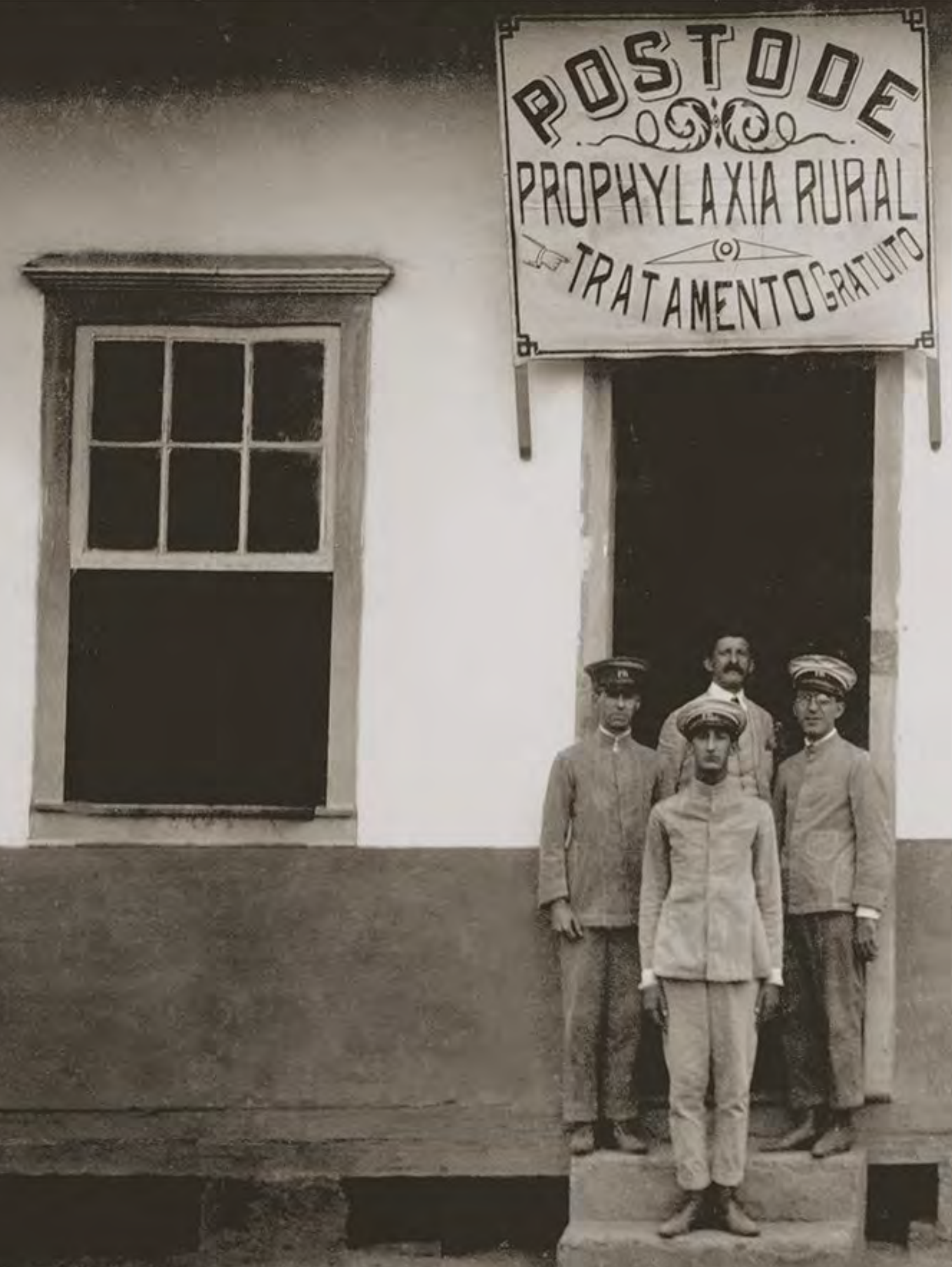

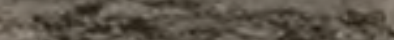



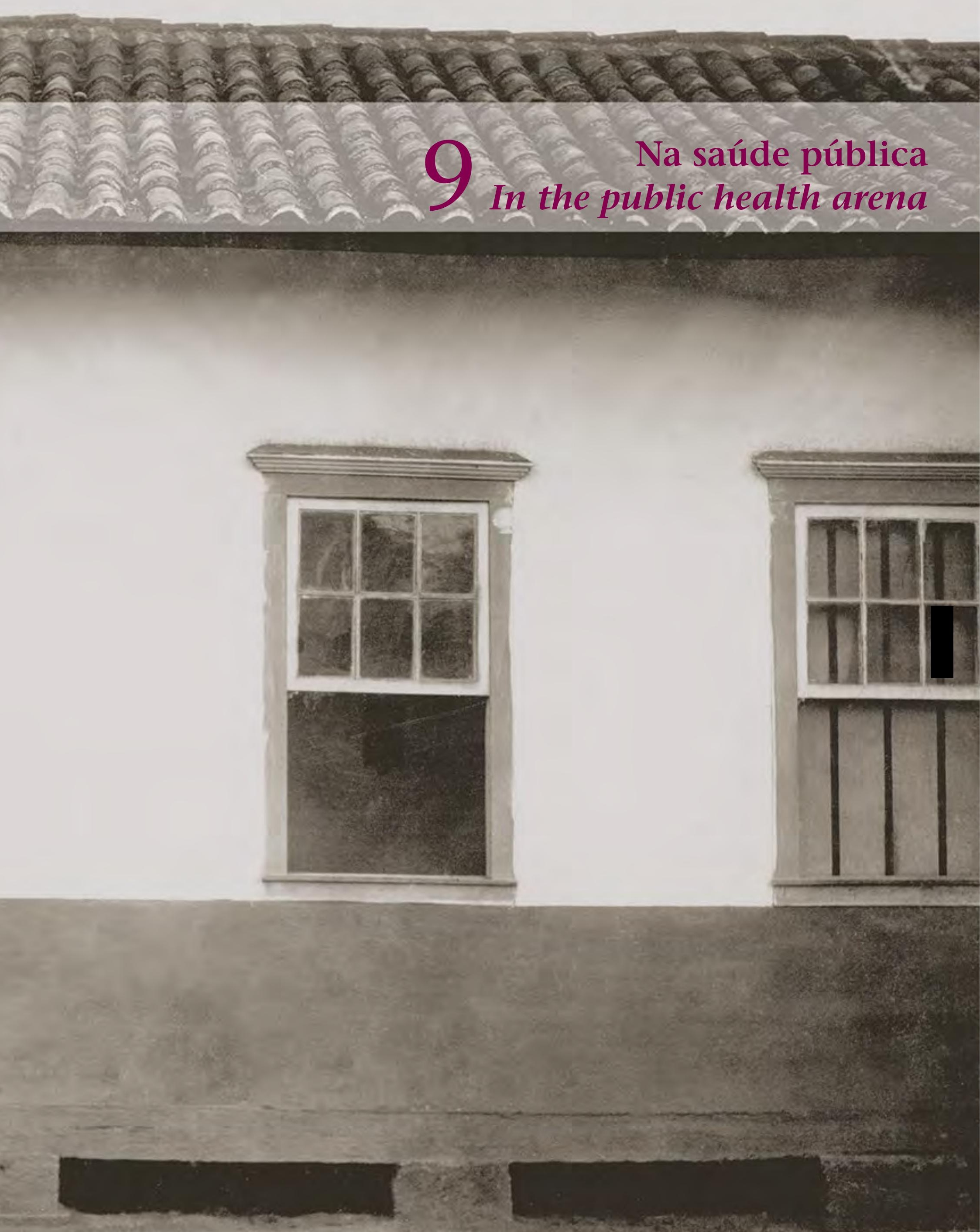
arlos Chagas teve atuação de destaque nos debates e nas ações sobre a saúde pública brasileira nas primeiras décadas do século XX.

Desde a descoberta da doença que leva seu nome, alertava sobre a importância das endemias rurais e a necessidade de combatê-las. Esta seria a bandeira principal do chamado movimento sanitarista que, entre 1916 e 1920, colocou no debate nacional o tema da saúde como elemento-chave para que o Brasil se tornasse efetivamente uma nação.

Em 1916, em discurso na Faculdade de Medicina do Rio de Janeiro, o médico e professor dessa escola Miguel Pereira denunciou as más condições de vida e de saúde no interior do país, assolado por endemias como a malária, a ancilostomíase e a doença de Chagas. Numa época de grande fervor nacionalista, declarou, em frase que se tornaria célebre e polêmica: "O Brasil é um imenso hospital". Suas palavras tiveram grande repercussão no debate político e intelectual sobre o país. Tal diagnóstico atualizava a denúncia de Euclides da Cunha (1866-1909) quanto ao isolamento e ao abandono dos sertões brasileiros.

O movimento sanitarista defendia a idéia de que o 'atraso' do Brasil não era resultado do clima tropical ou da composição racial de sua população, mas das doenças que afetavam as áreas rurais e da falta de ação do Estado diante dessa realidade. A campanha reivindicava que o governo federal aumentasse sua intervenção no campo da saúde pública e formalizou-se na Liga Pró-Saneamento do Brasil (1918-1920), criada e dirigida por Belisário Penna. Dela fizeram parte Chagas e muitos outros médicos, cientistas, intelectuais e políticos.

A denúncia do despreparo dos poderes públicos para enfrentar os problemas de saúde do país intensificouse nos últimos meses de 1918, quando chegou ao Brasil a devastadora pandemia de gripe espanhola. Para enfrentar a influenza no Rio de Janeiro, Chagas assumiu, a convite do presidente da República Wenceslau Braz, a responsabilidade de comandar a assistência médica à população. Providenciou a imediata instalação de hospitais emergenciais e postos de consulta em diferentes pontos da cidade e, por meio da publicação de anúncios nos principais jornais, buscou a colaboração de seus colegas de profissão para o enfrentamento da epidemia.

Ao tomar posse na presidência da República, Epitácio Pessoa (1865-1942) declarou que a reorganização dos serviços sanitários do país era uma prioridade nacional. Para comandá-la, nomeou Chagas, em outubro de 1919, para a Diretoria-Geral de Saúde Pública, que, em janeiro do ano seguinte, após intenso debate no Congresso Nacional, foi transformada em Departamento Nacional de Saúde Pública. Chagas assumiu sua direção, acumulando o cargo com suas funções à frente de Manguinhos.

O novo órgão fortaleceu a capacidade de intervenção e regulação do governo central na saúde pública. Chagas foi autor de um extenso Código Sanitário que modernizou a legislação sanitária brasileira. As ações de saúde, até então concentradas nas áreas urbanas, foram estendidas ao interior do país, sobretudo com a criação de postos de combate às endemias rurais. Para isso, foi decisiva a colaboração da Fundação Rockefeller, que atuava no país desde 1916 na profilaxia da ancilostomíase e da febre amarela. Os cuidados com a maternidade e a infância, a assistência hospitalar e o combate à tuberculose, sífilis e lepra foram também contemplados com serviços especializados.

Outra preocupação importante de Chagas à frente da saúde pública federal foi com a formação de profissionais especialmente destinados a essa área. Em 1922, com o apoio da Fundação Rockefeller, criou o Serviço de Enfermeiras, dirigido pela enfermeira norte-americana Ethel Parsons, a partir do qual fundou-se a Escola de Enfermagem Anna Nery. Ali seriam treinadas enfermeiras para atuar tanto no sistema hospitalar quanto no serviço de "enfermeiras visitadoras", visando a atender e orientar as famílias nos domicílios. Em 1926, organizou o Curso Especial de Higiene e Saúde Pública na Faculdade de Medicina da Universidade do Rio de Janeiro. Ministrado por pesquisadores de Manguinhos e sob a orientação de seu diretor, o curso garantia o acesso direto aos cargos da administração sanitária federal. Primeiro do gênero no país, foi um marco na institucionalização da carreira de sanitarista no Brasil.

Chagas deixou a direção do Departamento Nacional de Saúde Pública em 1926, ao final da conturbada presidência de Arthur Bernardes (1875-1955). O término de sua gestão foi marcado por fortes críticas: foi atacado na imprensa devido a um surto de varíola na capital e ao risco de uma epidemia de febre amarela. Seu sucessor no cargo foi Clementino Fraga (1880-1971).

No campo da saúde internacional, teve destacada atuação como representante brasileiro no Comitê de Saúde da Liga das Nações, a partir de 1922. No âmbito dessa associação, idealizou e dirigiu o Centro Internacional de Leprologia, inaugurado em 1934, com sede no Instituto de Manguinhos. 
arlos Chagas played a central role in Brazilian public health debates and initiatives during the early $\checkmark$ decades of the twentieth century.

After discovering the disease that carries his name, Chagas warned about the importance of rural endemic diseases and the need to fight them. This was the main plank of the so-called sanitation movement that made the issue of public health a matter of national debate from 1916 to 1920, as a key element of Brazilian nation-building.

In 1916, Miguel Pereira, physician and professor at the Rio de Janeiro School of Medicine, gave a speech at this institution in which he decried the poor living and health conditions in rural Brazil, beset by endemic diseases like malaria, ancylostomiasis, and Chagas disease. At a time of great nationalist zeal, he pronounced what would become a famous yet controversial phrase: "Brazil is an enormous hospital." His words had a major impact on the political and intellectual debate about Brazil. His diagnosis repeated the indictment by writer Euclides da Cunha (1866-1909), who had denounced the isolation and abandonment of the Brazilian hinterlands.

The sanitation movement defended the idea that Brazil's backwardness was not the product of its tropical climate or the racial make-up of its people but of the diseases afflicting its rural areas and the lack of government action in the face of this reality. The campaign called for the federal government to take firmer action in public health. It gave birth to the Pro-Sanitation League of Brazil (1918-1920), founded and directed by Belisário Penna. Chagas took part in it along with many other physicians, scientists, intellectuals, and politicians.

The accusation that the government was unprepared to deal with Brazil's public health problems grew louder in the closing months of 1918, when the devastating Spanish flu pandemic reached Brazil. At the invitation of the president of Brazil, Wenceslau Braz, Chagas was charged with the task of ensuring that the population received medical assistance when the flu hit Rio de Janeiro. He immediately had emergency hospitals and consultation posts set up around the city and, through announcements in major newspapers, encouraged his colleagues' collaboration in combating the epidemic.

When he took office, President Epitácio Pessoa (1865-1942) declared the reorganization of the country's sanitary services a national priority. To lead this effort, he appointed Chagas to head up the General Directorship of Public Health, in October 1919. After heated debate in Congress, the Directorship was transformed into the National Department of Public Health in January of the following year. Chagas was made director, while still holding his post as head of Manguinhos.

The new Department enhanced the central government's ability to take action in public health and to enact regulations. Chagas drafted a comprehensive Sanitary Code that modernized the nation's sanitary laws. Public health interventions that had previously been concentrated in urban areas were extended to the interior, particularly through the creation of sanitary posts for fighting rural endemic diseases. Decisive collaboration came from the Rockefeller Foundation, which had been working to prevent ancylostomiasis and yellow fever in Brazil since 1916. Mother and childhood care, hospital care, and the fight against tuberculosis, syphilis, and leprosy were also the subject of specialized services.

Another important concern of Chagas's during his tenure as head of the federal public health system was the training of specialized personnel. In 1922, with the support of the Rockefeller Foundation, he created the Nursing Service, directed by American nurse Ethel Parsons. This agency was the foundation for the Anna Nery School of Nursing. There, nurses were trained to work both in the hospital system and as visiting nurses who cared for and counseled families at home. In 1926, he organized the Special Course in Hygiene and Public Health at the University of Rio de Janeiro's School of Medicine. Run by Manguinhos researchers under the guidance of its director, the course guaranteed its graduates direct access to posts within the federal public health organization. The first of its type in the country, it was a landmark in the institutionalization of the career of sanitarian in Brazil.

Chagas left his position with the National Department of Public Health in 1926 at the close of President Arthur Bernardes' (1875-1955) troubled term in office. Chagas was the target of heavy criticism at the end of his administration, with the press coming down hard on him because of an outbreak of smallpox in Rio and the risk of a yellow fever epidemic. His successor was Clementino Fraga (1880-1971).

On the world stage, Chagas played a prominent role as the Brazilian delegate to the League of Nations' Health Committee, starting in 1922. Under the aegis of this institution, he conceptualized and directed the International Leprology Center, which opened its doors at the Manguinhos Institute in 1934. 


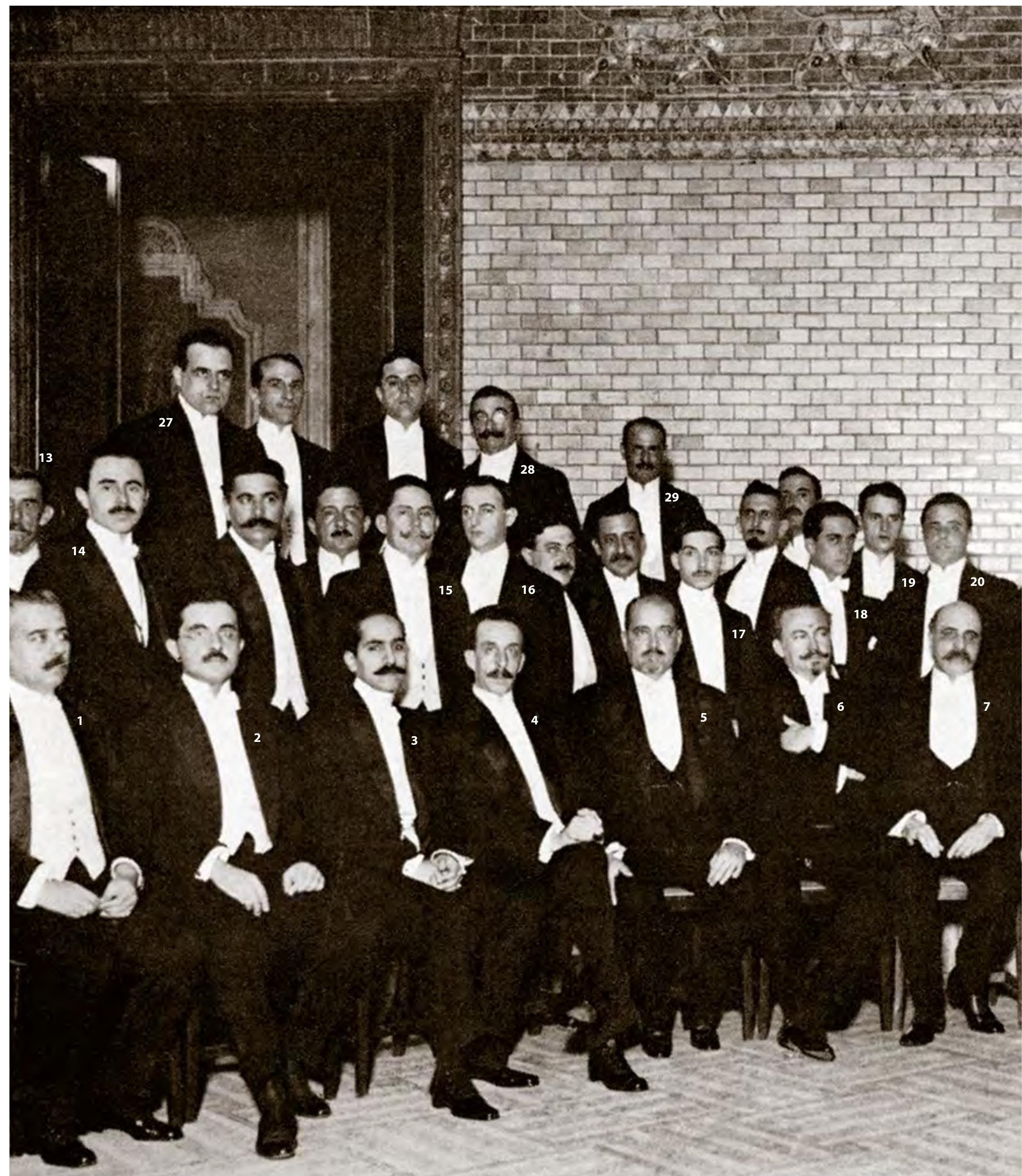




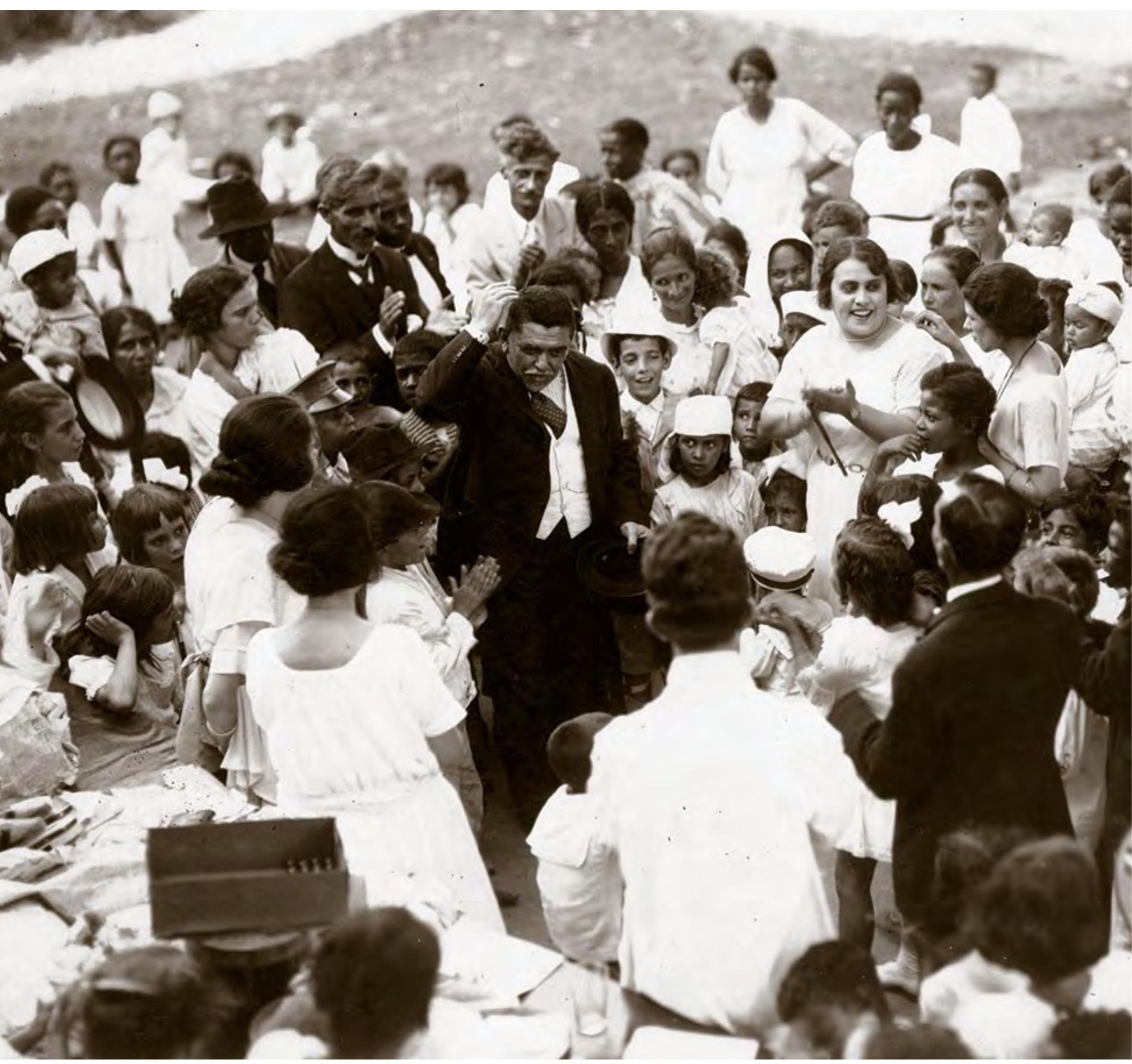

Belisário Penna, o autoproclamado "apóstolo do saneamento rural" e diretor da Liga Pró-

Saneamento do Brasil, discursa para moradores de Pilares, no Rio de Janeiro Acervo Casa de Oswaldo Cruz

Belisário Penna, self-proclaimed "apostle of

rural sanitation" and director of the Pro-

Sanitation League of Brazil, speaking before residents of Pilares, Rio de Janeiro 


\section{BELISARIO PENNA}

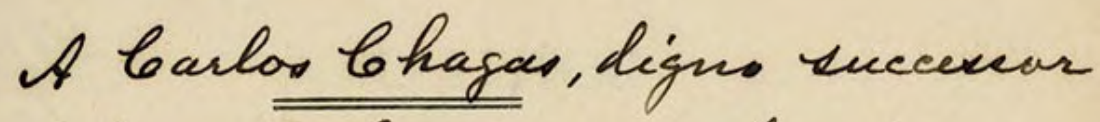 o Ouvals brux, con elevars ofreeco e frofunda ancisade $24-1-918$ s Selukaró Saneamento do Brasil}

Sanear o Brasil é povoal-o;

é enriquecel-o;é moralisal-o.

19. EDIÇก̃O
A saúde é a geratriz da alegria, do trabalho profícuo, da riqueza e do progresso. $A$ doença gera a tristeza, $o$ desânimo, a miséria e o atraso. Não há um só país culto e adiantado que não deva à higiene o seu progresso e a sua força.

Belisário Penna

Good health engenders happiness, productive work, wealth, and progress. Disease produces sorrow, despondency, poverty, and backwardness. There is not one single welleducated, advanced country that does not owe its progress and might to hygiene.

Belisário Penna

TYP. REVISTA DOS TRIBUNAES CARMO 55-RIO DE JANEIRO 1918 
Abaixo a bicharia que devora o brasileiro! Ter saúde é a grande qualidade de um povo. Tudo mais vem daí.

Jeca Tatu, personagem de Urupês, de Monteiro Lobato

Down with the hordes of bugs devouring the Brazilian people! Good health is a people's greatest asset. Everything else follows from it.

Jeca Tatu, character from Brazilian writer Monteiro Lobato's Urupês

\section{A CASA DO JECA ANTES DO SANEAMENTO}

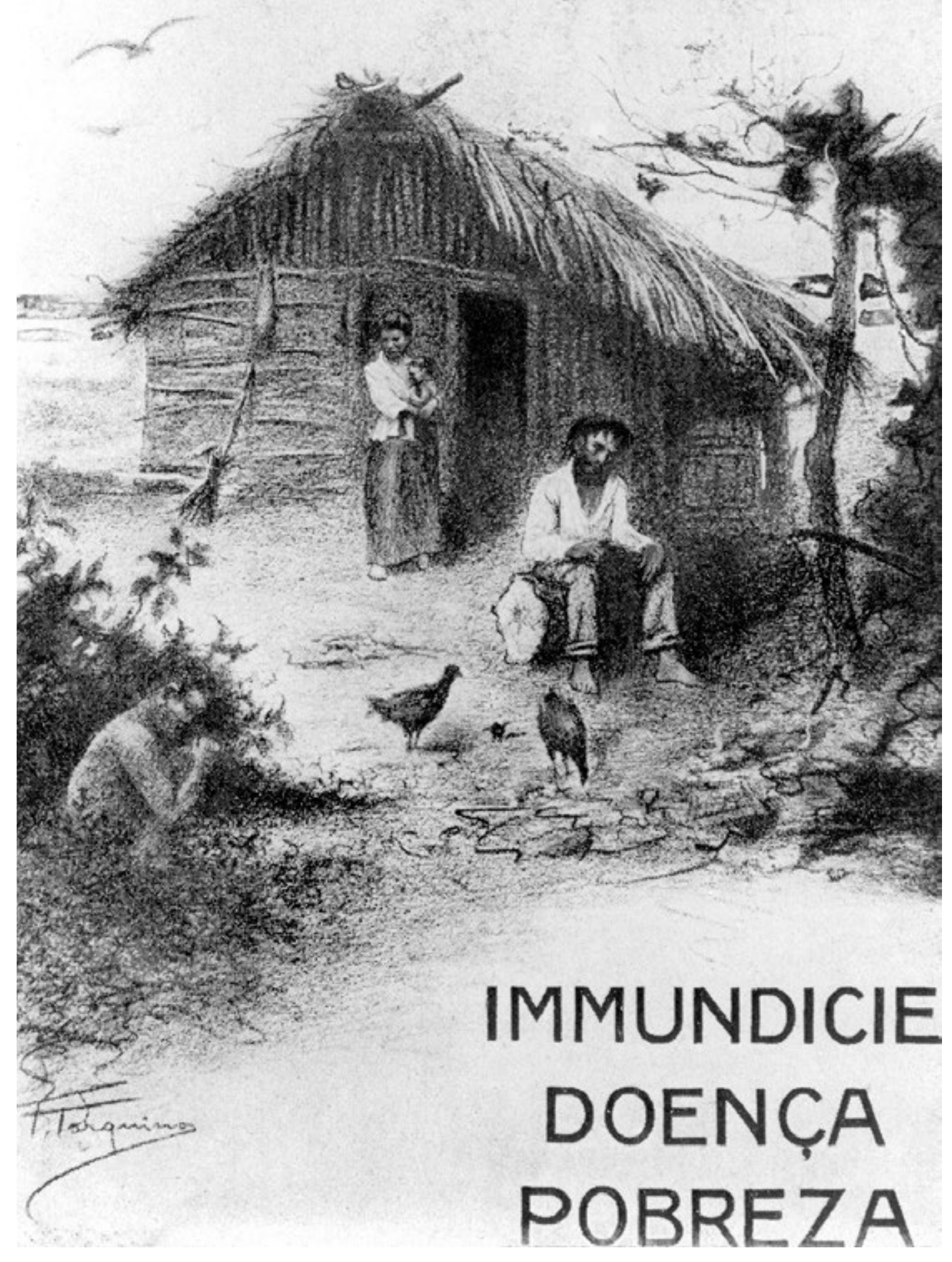




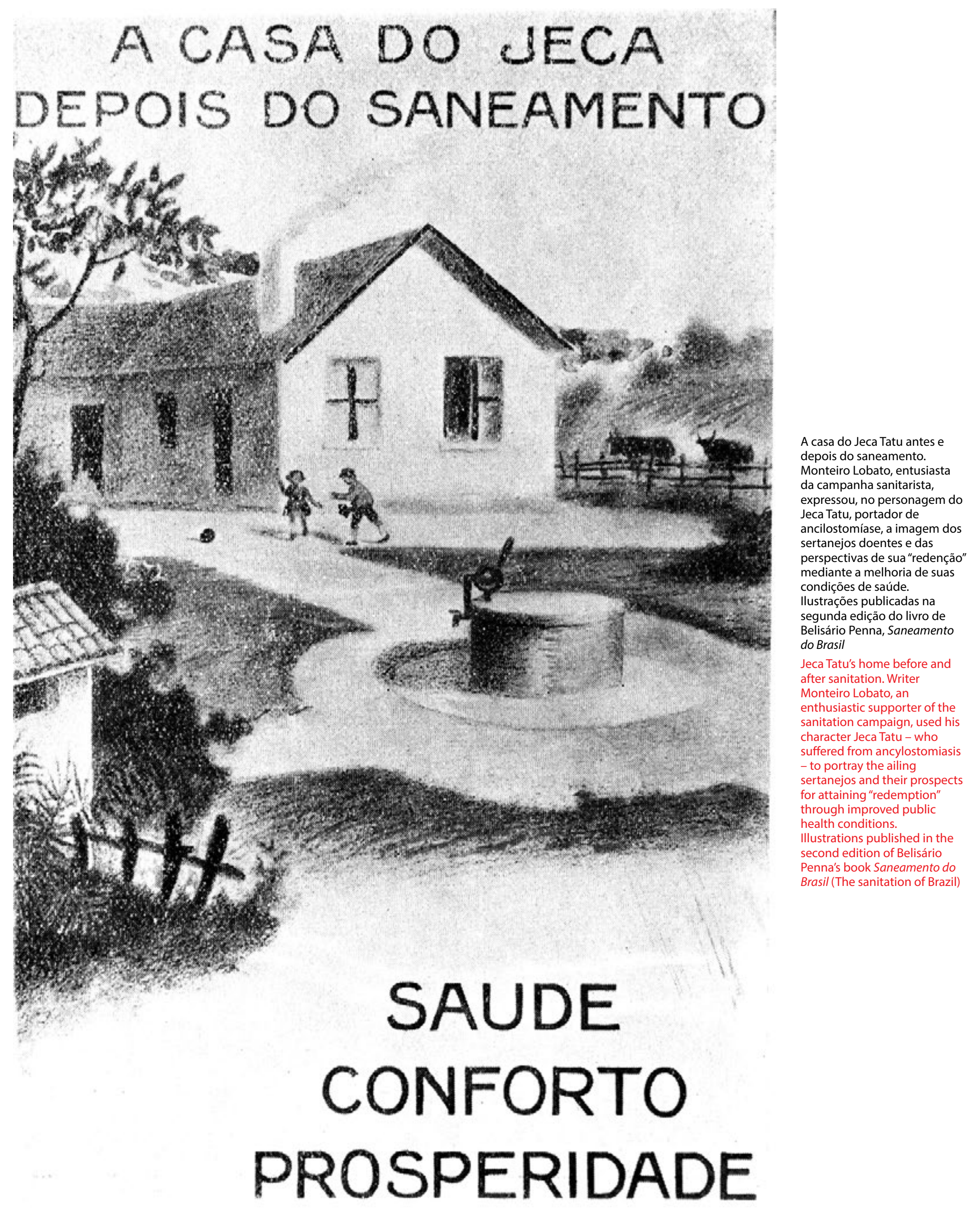




\section{MAATS UIMA ?}

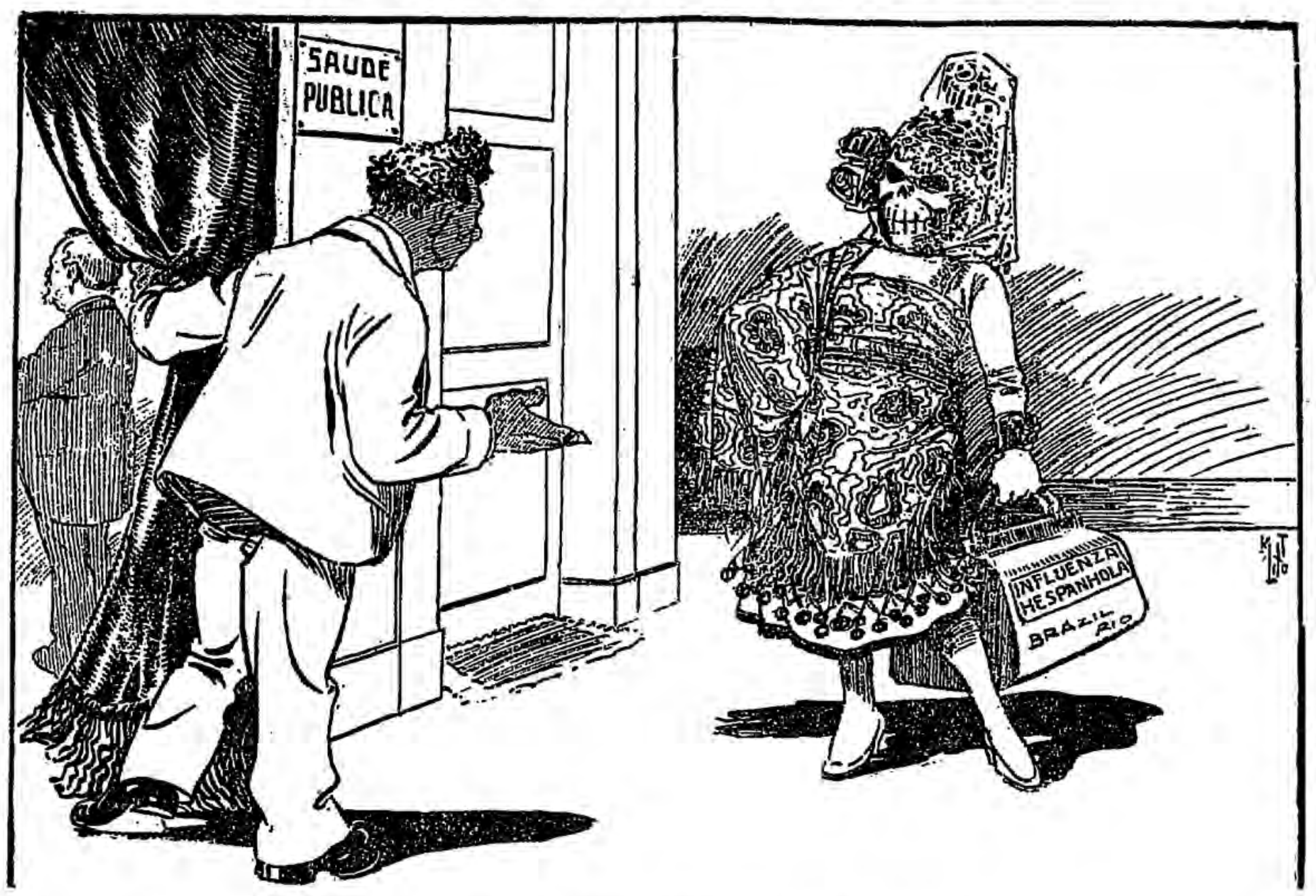

Ella - Hagn usted el favor de decir al airector yue estoy a sus orden is

Continuo - llas.. creio que nảo ha mais logar...

Fila - la como no, gi el doctor Seidl me dijo que yo aqui tenia la collocacion segurn? Esto es un cmbuste !...

Mais uma?

Gazeta de Noticias, 29 set. 1918

Acervo Fundação Biblioteca Nacional

"Another one?"

Gazeta de Noticias, Sep. 29, 1918 


\section{O presidente da Republica manda distri= buir caldo e pão á pobreza}

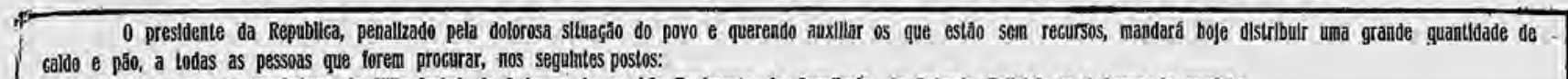

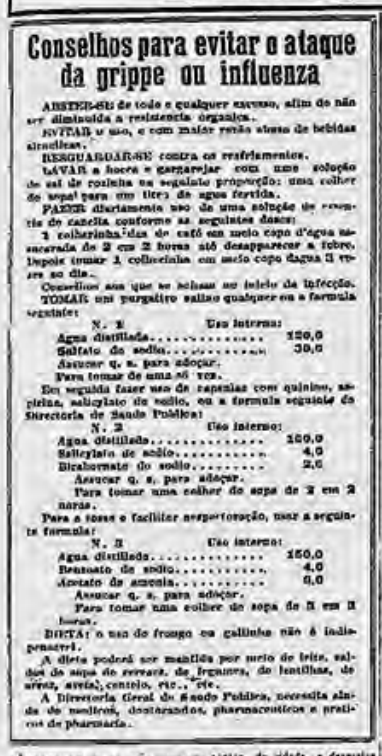

\section{O COMMERCIO PODE ABRIR \\ o prefeito belkoir ama circular declarando que, apesar dos dias feriados, as casas de commercio O prefeito balxon ama circular declarando que, apesar dos dias feria
poderüo abrir us portas e vender as mercadorias que o pablico reclamar,}

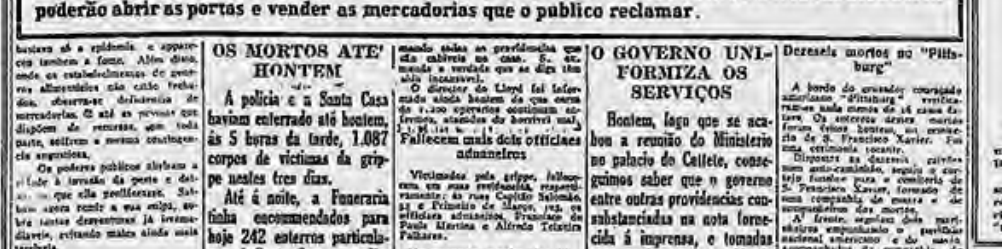

Os pastos de sacconro

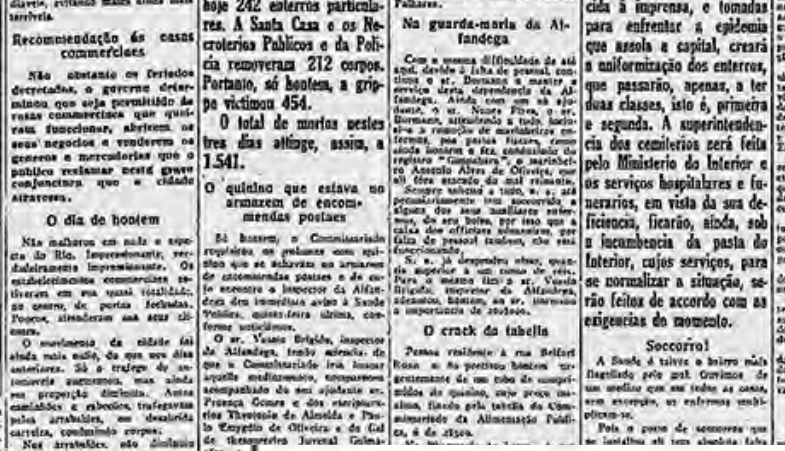

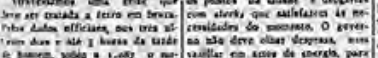
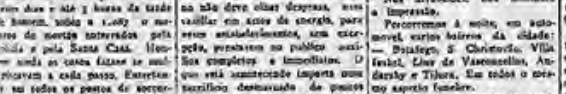

0 dr. Carlos Chagas encarregzdo de crear postos
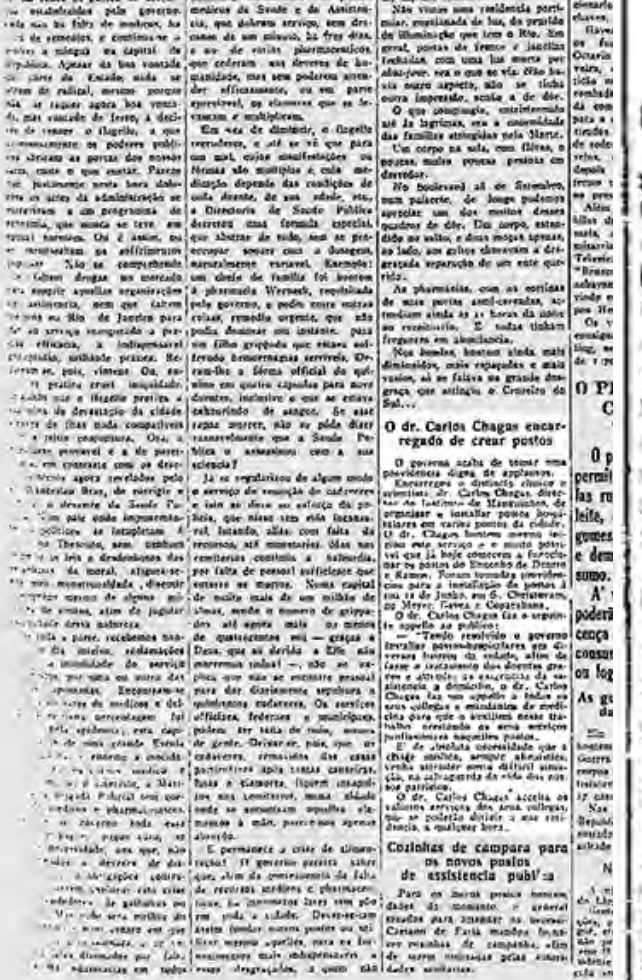

O poverno acsiba de tomar uma providencia dignz de applausos.

Encarregon o distincla clistico e scientist:, it. Carlos Chagas, dirteinr do Justittico de Mankuizhos. de organigar $z$ installar postos hosphtalares cm varios pontos da sidinde. 0 dr. Clages hantrm mesmo in:ciou este gerviça e é muto possisel que ji hoje comesem 2 furrecionar es postns do Engentio de Dentro c Ramos. Foram tomadas providemcias para a ingtallación de postos a

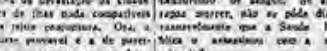
niza it de Jutnho, ens $\mathrm{S}$. Chrisiovam, ao Meyer. favera e Copjeabana.

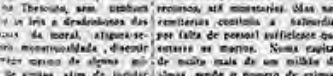
O Ur. Curlos Chagkas fat o seguinle appello no publico:

- Tendo resolvido a soverno installar postoshospit=lares em di. versos bairros da cillade, afím the fazer a trataulenlo dos doentea gra-

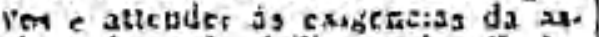
aistencia a donsicilio, o dr. Caslos Chagos fisz vim appeltin at toulas vo seus volleras e estudanteo de medicina para que o auxilien nesse tra. lasiho nrestando or setrs servicos jrofiskimace nayurellex rostos.

E' de abrolusa necessidade que a emine inediea. sempre alustistica, venhia attroter nesta difficil vimia.

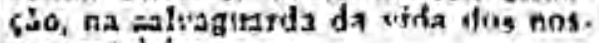
con patricion.

o dr. Curiog Clsianses atietica os

O presidente da Republica manda distribuir caldo e pão á pobreza Correio da Manhã, 22 out. 1918 Acervo Fundação Biblioteca Nacional valiosns acricos tina metic rallegal,

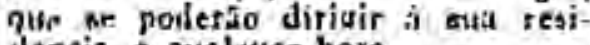
and soup distributed to the poor Correio da Manhã, Oct. 22, 1918 dencia, a nualiguer hora. 
Chagas e o presidente da República

Wenceslau Braz, em

posto de atendimento no Méier, bairro do Rio

de Janeiro, durante

a epidemia de gripe

espanhola

Careta, 9 nov. 1918

Acervo Fundação Biblioteca Nacional

Chagas and Brazilian president Wenceslau Braz, at a healthcare post in the Rio de Janeiro neighborhood of Méier during the Spanish flu epidemic Careta, Nov. 9, 1918

O Rio apavorado

O Malho, 26 out. 1918 Acervo Casa de Rui Barbosa

"A terrified Rio"

O Malho, Oct. 26, 1918

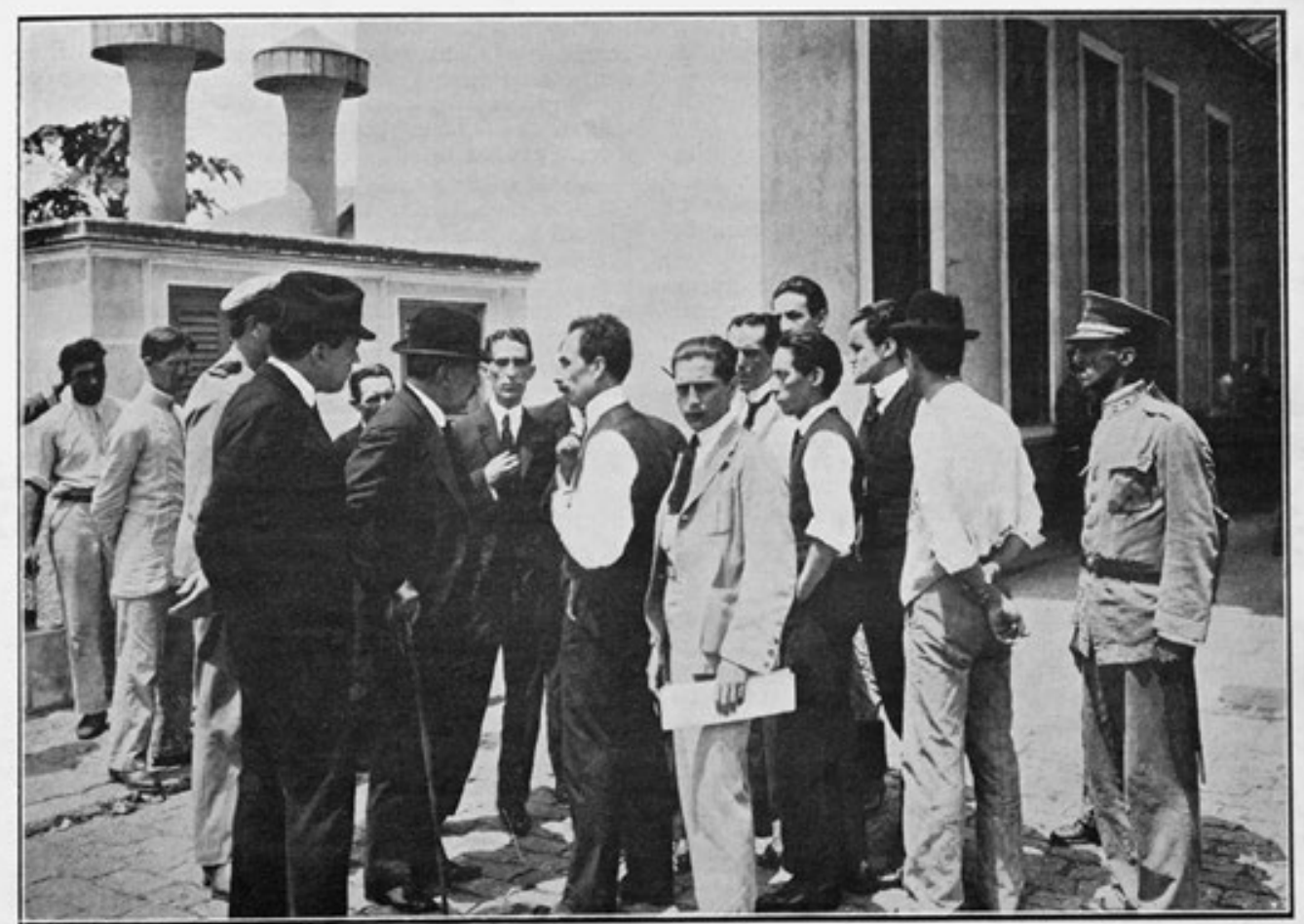

No Posto do Meyer, o dr. Carlos Chagas dá informaçies ao Chefe da Naçäo sobre ämarcha dá, epidemia. $\rightarrow-\infty$ $\rightarrow$

\section{OMALHO}

RIO DE JANEIRO, 26 DE OUTUBRO DE 1918:: NUMERO AVULSO, 100 Réis

(3) Rio apavorado

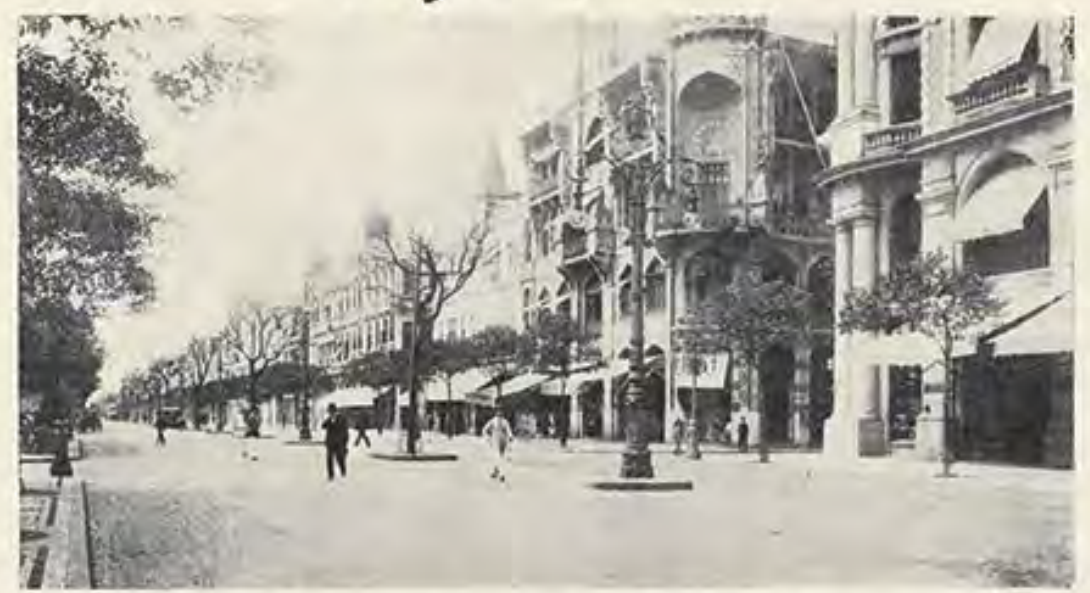

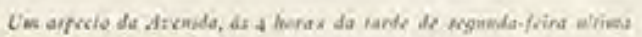

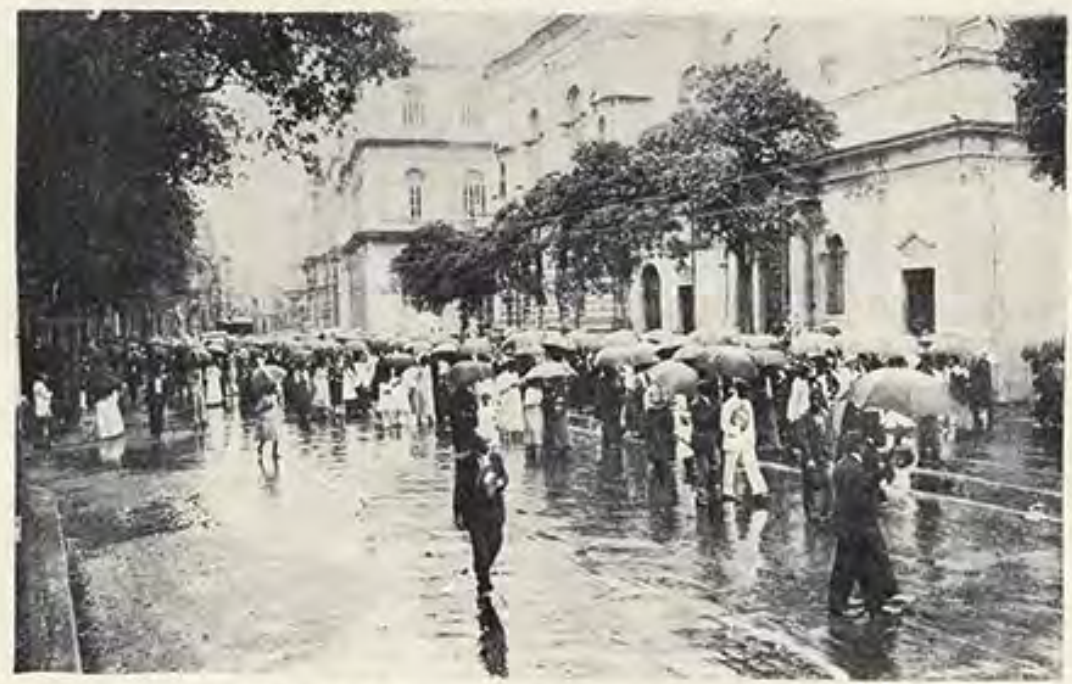

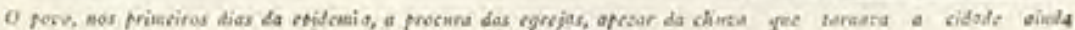
whit tivie 


\section{$=$ Correio da Manhã - ANINO XVIII- IV. 7.18 \\ O PRESTDENTR DA REPUBLIGA TRANQUULLLZA A POPULAGÃ̃}

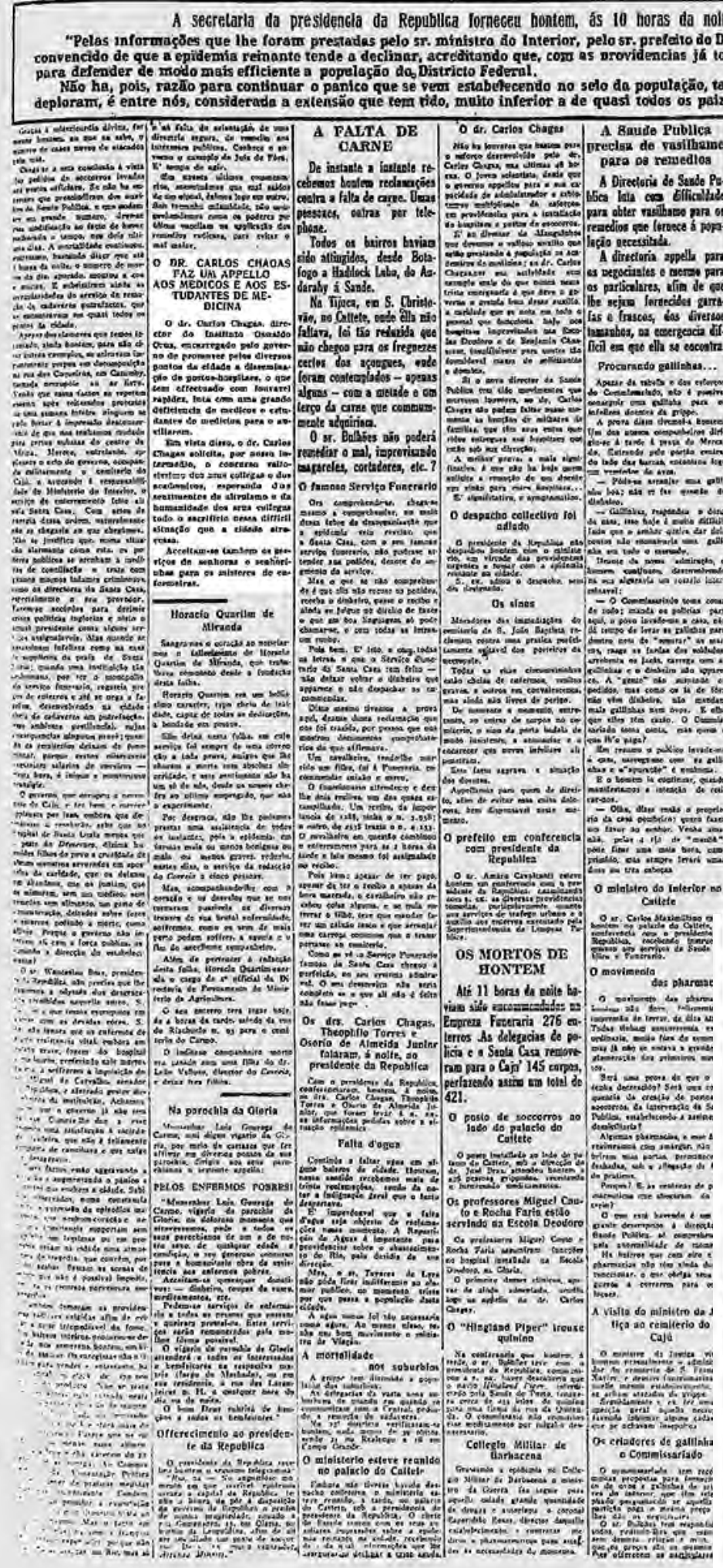

O presidente da Republica tranquilliza a população

Correio da Manhã, 24 out. 1918

Acervo Fundação Biblioteca Nacional

"President

Correio da Manhã, Oct. 24, 1918

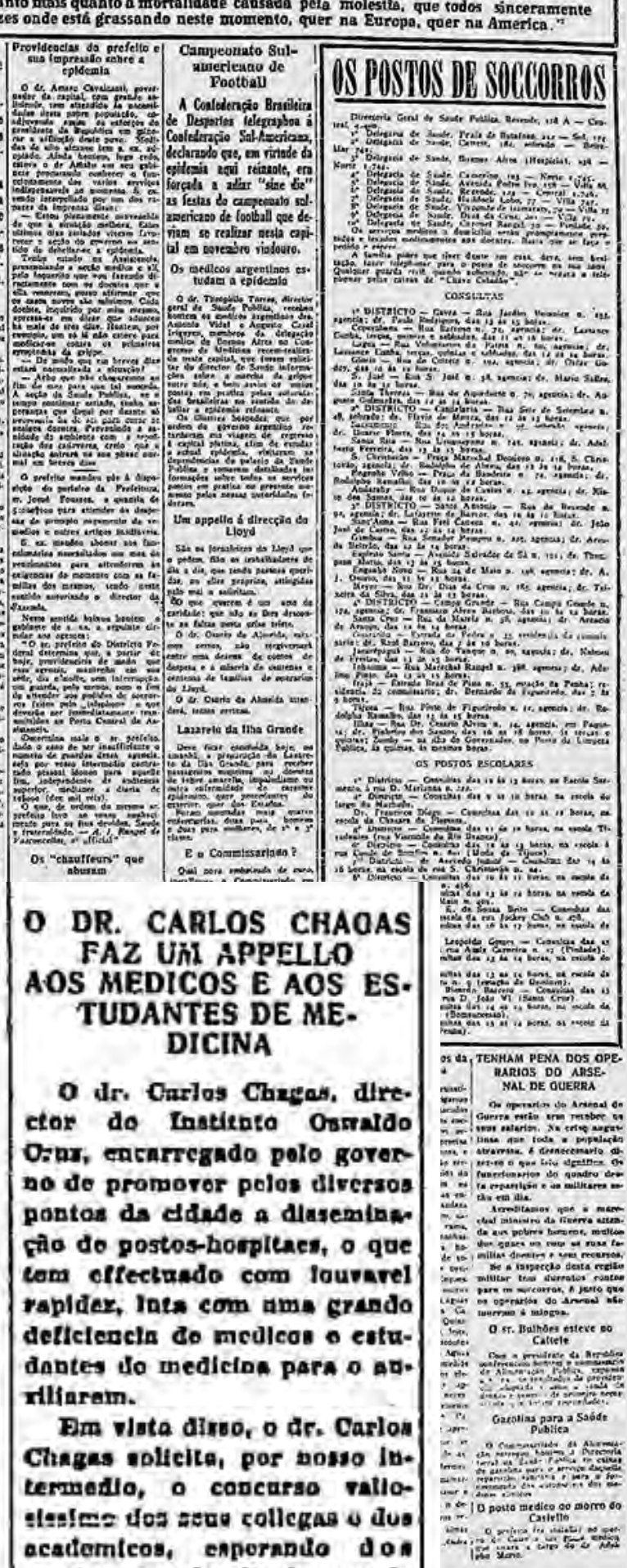
nentituentos de altraismo o da lramantdado dos sean collezas todo o sacriflela bessa alfficit stragito que a cliado atrareana.

Acceltam-ie tambera on kerricos do senhorag o sedhárluba para os misteres do eatormelras. 
No agudo da epidemia, num dia em que não havia mais jeito de transportar tanto morto, o Chefe de Polícia já dava o desespero quando a solução veio do Jamanta, $o$ célebre folião, figura de prol do Carnaval carioca. (...) Ele conhecia admiravelmente $o$ seu Rio de Janeiro e por um desses caprichos de boêmio aprendera, em passeatas noturnas, a dirigir bondes. Pediu e obteve dos seus superiores um bagageiro com dois taiobas e vasculhou com eles a cidade de norte a sul Fábrica de Chitas, Tijuca, Andaraí, Aldeia Campista, Vila Isabel, Méier, Engenho de Dentro, Piedade, Cascadura, Penha Circular, Benfica - apregoando que todos pusessem para fora seus mortos (Bring out your deads!). Bonde e reboques cheios de caixões empilhados e de amortalhados em lençóis, o motorneiro solitário batia para o Caju.

Descarregava. O dia já ia alto mas ele voltava a nove pontos, varejava Laranjeiras, Flamengo, Botafogo, Jardim Botânico, Ipanema, Copacabana - pegando mais defuntos. Lotava. Já noite, passava a sinistra composição como o Trem Fantasma ou o navio de Drácula - entupida de carga para o São João Batista. Fez isso uns dois ou três dias que marcaram para sempre sua lembrança.

Pedro Nava

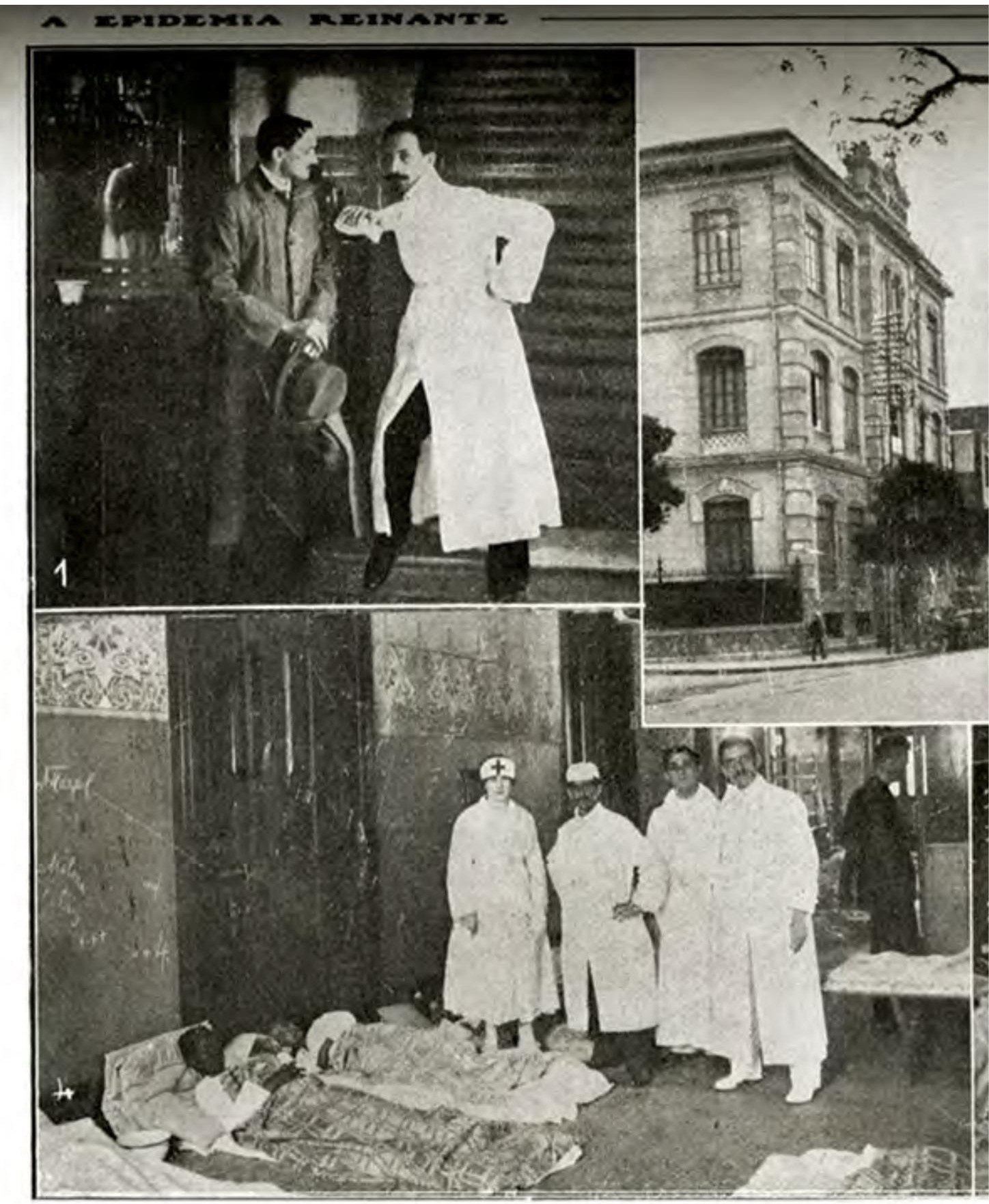

1 - O Dr. Carlos Chagas, á direita, director do Instituto Oswaldo Cruz.

2 - Ediïicio da Escola Deodoro, na Gloria, transformado em Posto de Assistencia.
Assim é que é! Viva a folia! Viva Momo - Viva a Troça! Não há tristeza que possa Suportar tanta alegria. Quem não morreu da Espanhola, Quem dela pôde escapar Não dá mais tratos à bola Toca a rir, toca a brincar...

Música de carnaval cantada no Club dos Democráticos Correio da Manhã 1919 


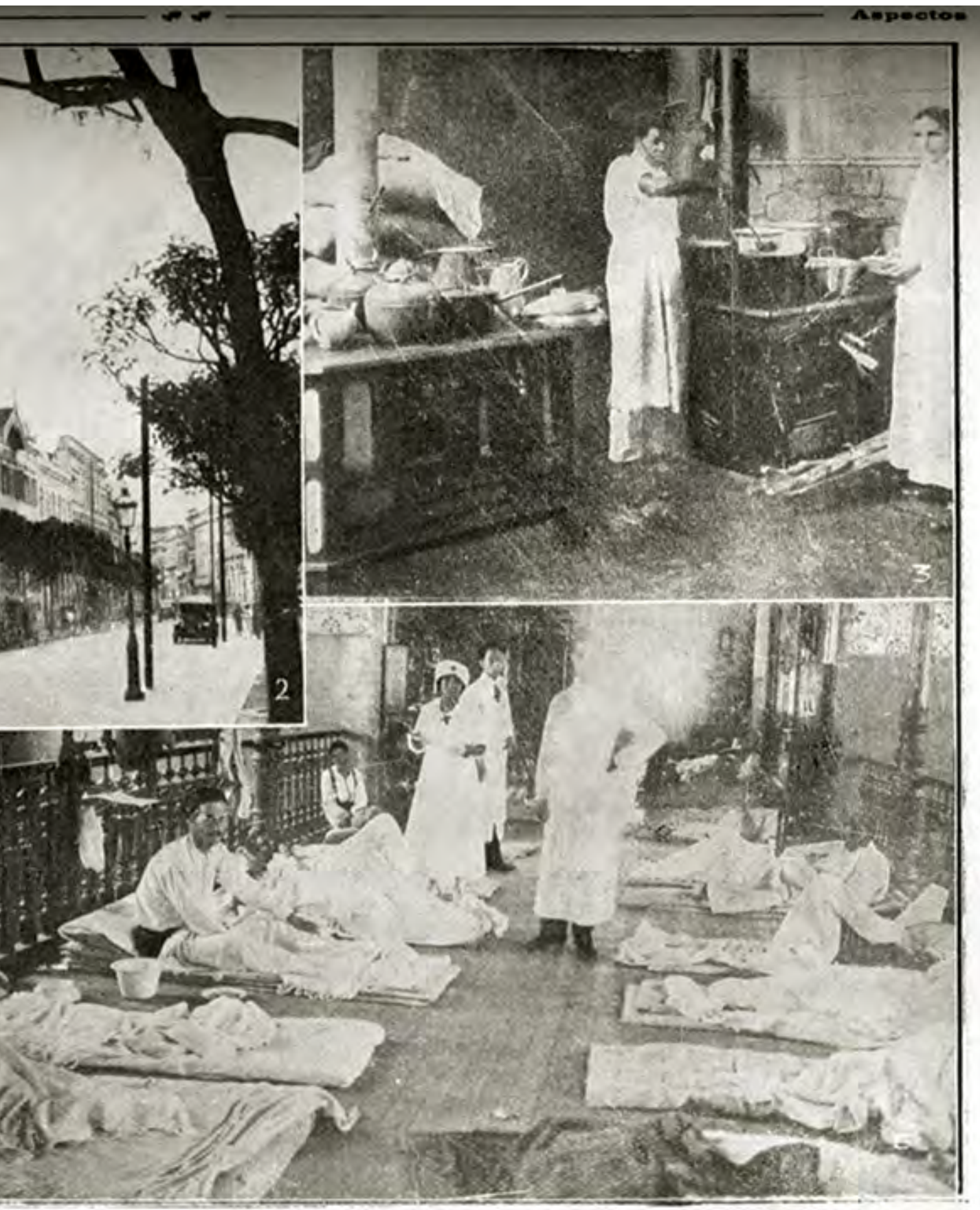

3- A cosinha do mesmo posto.

;-5 - Enfermarias na Escola Deodoro.
A epidemia reinante Fon-Fon, 2 nov. 1918 Acervo Casa de Rui Barbosa "The raging epidemic" Fon-Fon, Nov. 2, 1918

This is it! Viva merriment!

Viva the King of Carnival! Viva revelry!

Ain't no sorrow can resist

All this happiness.

If the Spanish flu didn't get you,

If it didn't kill you off,

Don't let it worry you no more.

Get back to the laughter, get back to the fun...

Carnival tune sung at the social organization known as the Democrats Club Correio da Manhã, 1919

At the height of the epidemic, one day when there was no way left to transport so many dead and the Chief of Police was at the end of his rope, the solution came from the famed reveler Jamanta, a notable figure from Rio de Janeiro's Carnival. (...) He knew his Rio de Janeiro remarkably well, and on some bohemian lark, during nighttime outings, had learned to drive trolleys. One of his superiors responded to his request for a carriage and two closed baggage cars and he used them to scour the city from north to south Fábrica de Chitas, Tijuca, Andaraí, Aldeia Campista, Vila Isabel, Méier, Engenho de Dentro, Piedade, Cascadura, Penha Circular, Benfica - urging everyone to put their dead outside (Bring out your deads! [English in the original]). Carriage and baggage cars piled high with caskets and shrouded corpses, the lone motorman would head to the cemetery in Caju. Unload. The day grew late but back he would go at top speed, combing Laranjeiras, Flamengo, Botafogo, Jardim Botânico, Ipanema, Copacabana, picking up more bodies. Filling up. Nighttime already, the ominous string of cars would pass by like the Ghost Train or Dracula's ship, crammed with cargo for São João Batista cemetery. He did this for two or three days that stuck in his memory forever. 

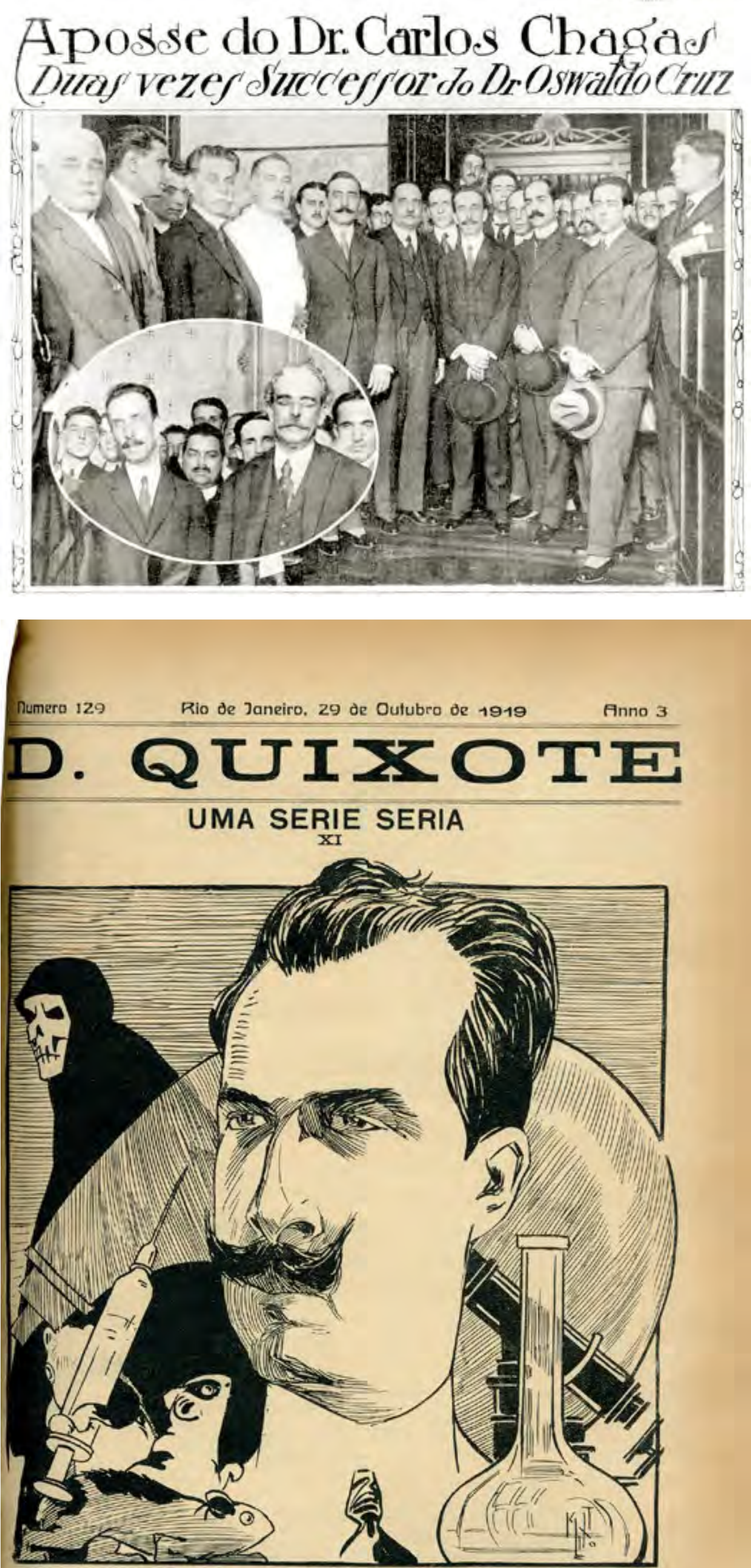

Tu gue tens virtudes magas,

Do Oswaldo as liç̧óes propagas,

Eua perda nos pagas

Carlos Chagas, Carlos Chagas !
Posse de Chagas na

Diretoria-Geral de Saúde Pública Revista da Semana,

11 out. 1919

Acervo Casa de Oswaldo Cruz

Chagas taking office at the

General Directorship of Public

Health

Revista da Semana, Oct. 11, 1919

Uma serie seria

D. Quixote, 29 out. 1920

Charge de Kalixto, por ocasião

da nomeação de Carlos Chagas

para a Diretoria-Geral de Saúde Pública

Acervo Casa de Oswaldo Cruz

"A serious series"

D. Quixote, Oct. 29, 1920

Cartoon by Kalixto published

when Carlos Chagas was

appointed to the General

Directorship of Public Health 


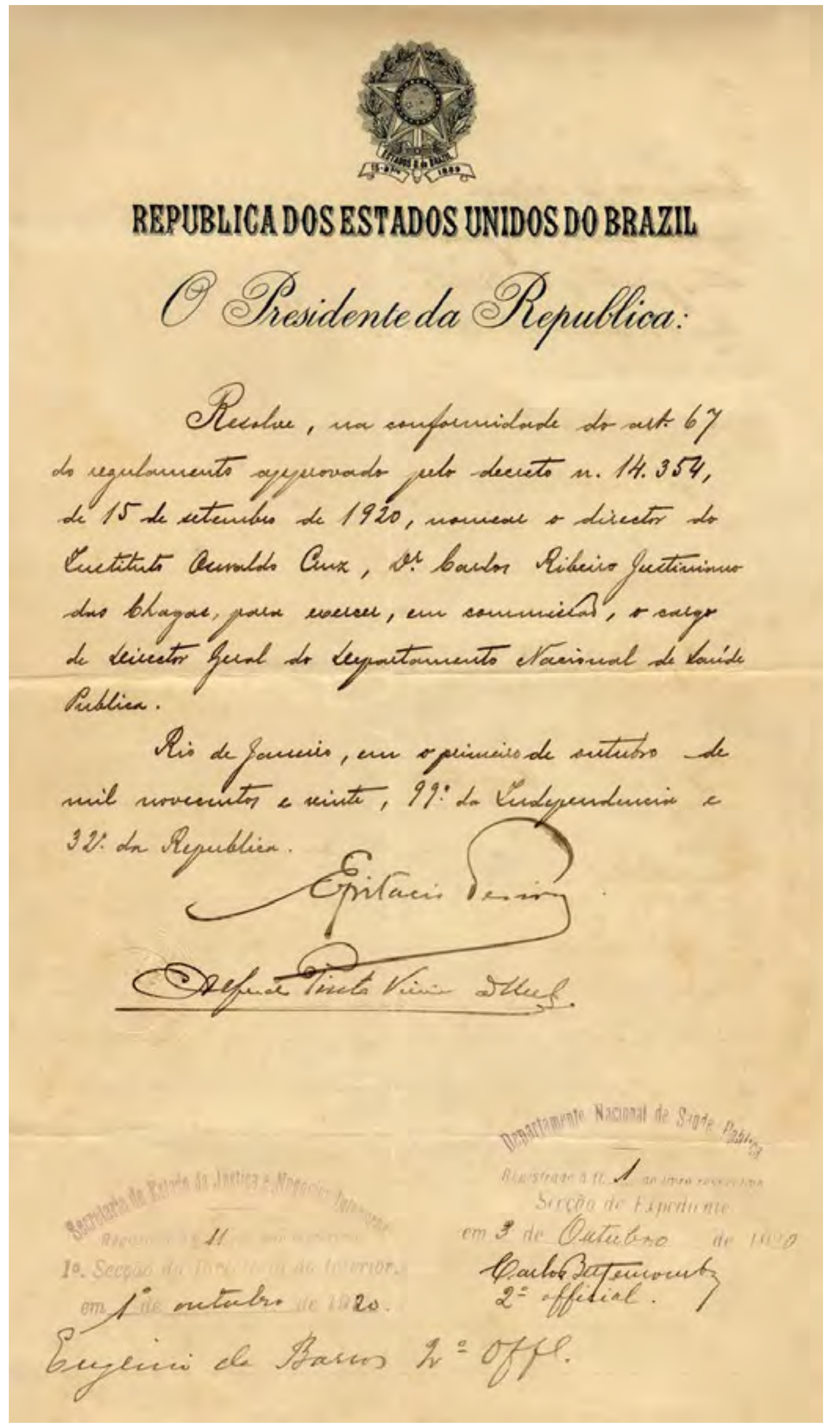

Ao assumir as funções do cargo de diretor-geral de saúde pública, não desconheço as dificuldades de seu desempenho, e sei apreciar bem alto as obrigações de trabalho que me são impostas pela confiança do governo.

Carlos Chagas

As I assume the duties of the office of director general of public health, I am not unaware of the challenges of this role, and I know full well how to appreciate the assignment with which the government has entrusted me. 

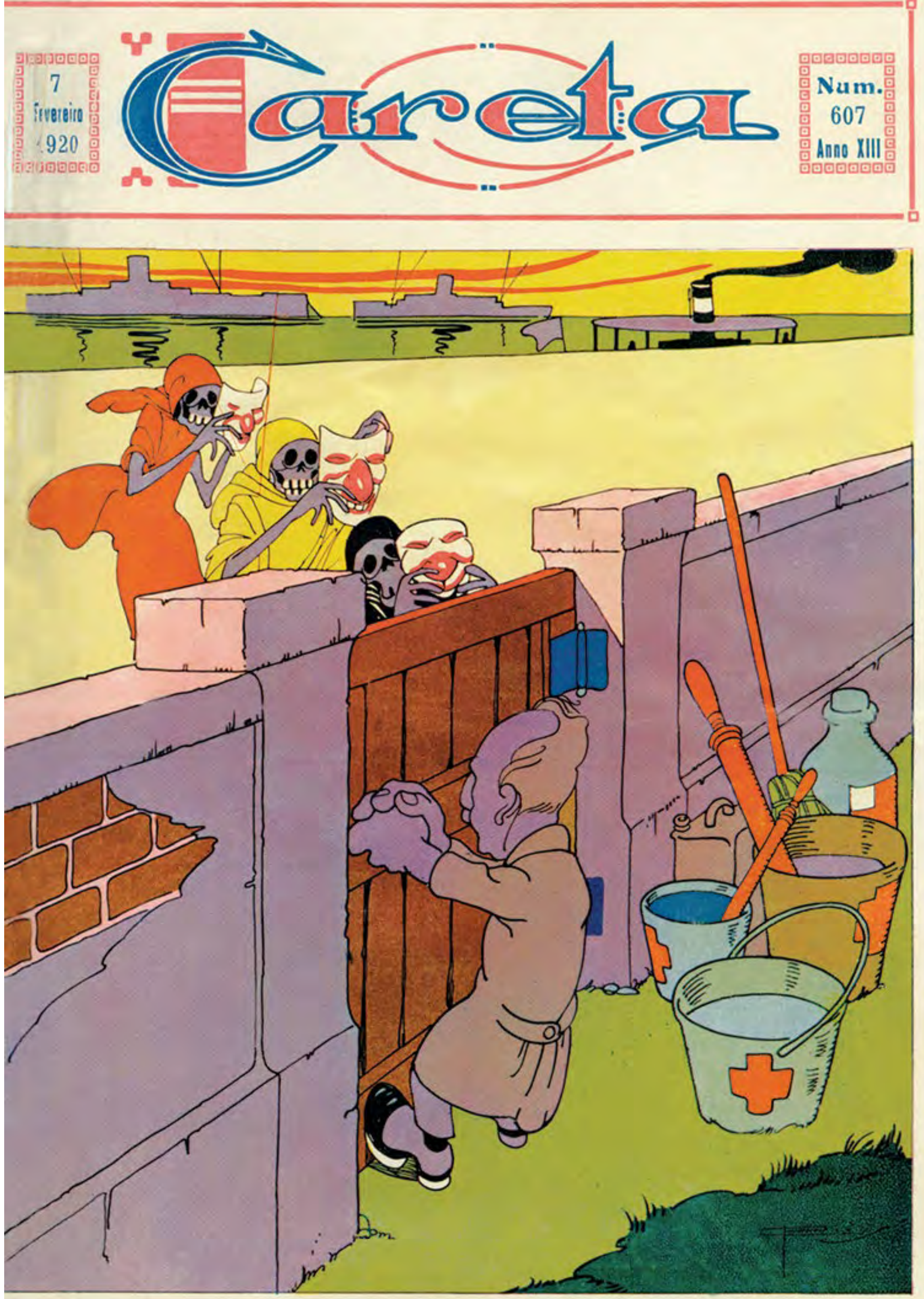

O PORTEIRO IMPLACAVEL.

Foi vedada a entrada aos primeiros mascarados. 


\section{COM A MÃ̃ NA MASSSA}

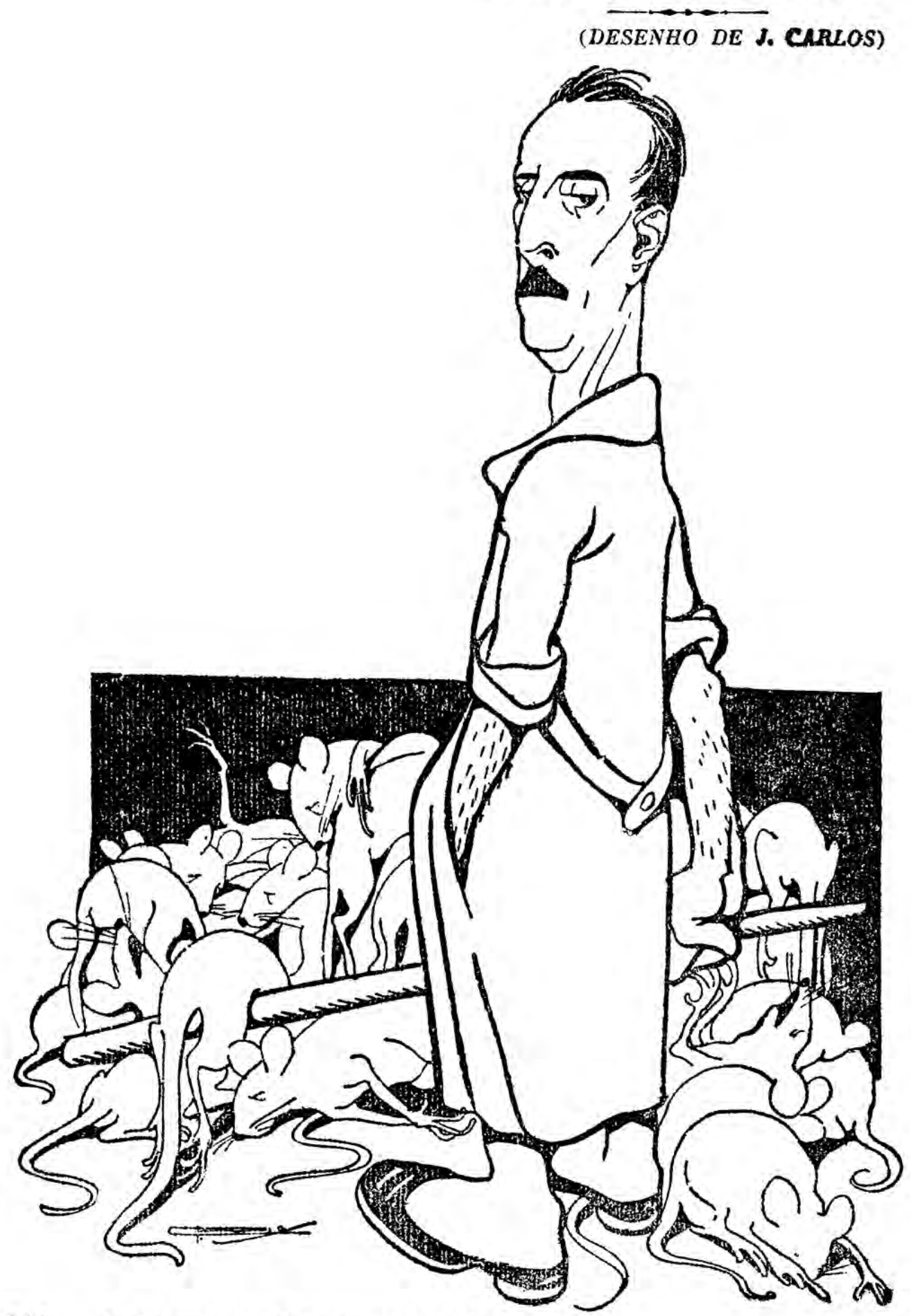

Cabcas - Acabarasos tambern com as "ratas".

$\begin{array}{ll}\text { O porteiro implacável } & \text { Com a mão na massa } \\ \text { Careta, 7 fev. 1920 } & \text { Charge de J. Carlos (José } \\ \text { Charge de J. Carlos } & \text { Carlos de Brito e Cunha, 1884- } \\ \text { (José Carlos } & \text { 1950) } \\ \text { de Brito e Cunha, } & \text { Acervo Casa de Oswaldo Cruz } \\ \text { 1884-1950) } & \text { "Getting one's hands dirty" } \\ \text { Acervo Casa de Oswaldo Cruz } & \text { Cartoon by J. Carlos } \\ \text { "The relentless doorman" } & \\ \text { Careta, Feb. 7, 1920 } & \\ \text { Cartoon by J. Carlos } & \end{array}$

Sob o ponto de vista

sanitário, não nos parece, de fato, que o festival de Momo seja, nas atuais circunstâncias, tão inócuo como as entrevistas fazem crer que pensa o Dr. Carlos Chagas. Mas S. Ex. éo principal responsável pela saúde pública, e, uma vez que a sua opinião parece inclinarse, no sentido de não ver inconveniente nos folguedos populares, não seremos nós que, mais realistas do que o rei, insistiremos em discutir a conveniência de adiar o entrudo, a poeira, a aglomeração e a fadiga dos dias heróicos do carnaval, para uma ocasião, em que mais afastada de nós estivesse a companhia da gripe.

O Paiz, 1920

From a sanitary standpoint, it does not actually seem to us that Carnival, under present circumstances, is as harmless as interviews lead us to believe Carlos Chagas thinks it is. But this gentleman bears primary responsibility for public health, and since his opinion seems to lean towards finding nothing inappropriate about popular revelry, far be it from us, more realistic than the king, to keep calling for discussions about the advisability of postponing the capers, the prancing, the crowds, and the fatigue of the heroic days of Carnival until an occasion when we are not in such close company with the flu.

O Paiz, 1920 


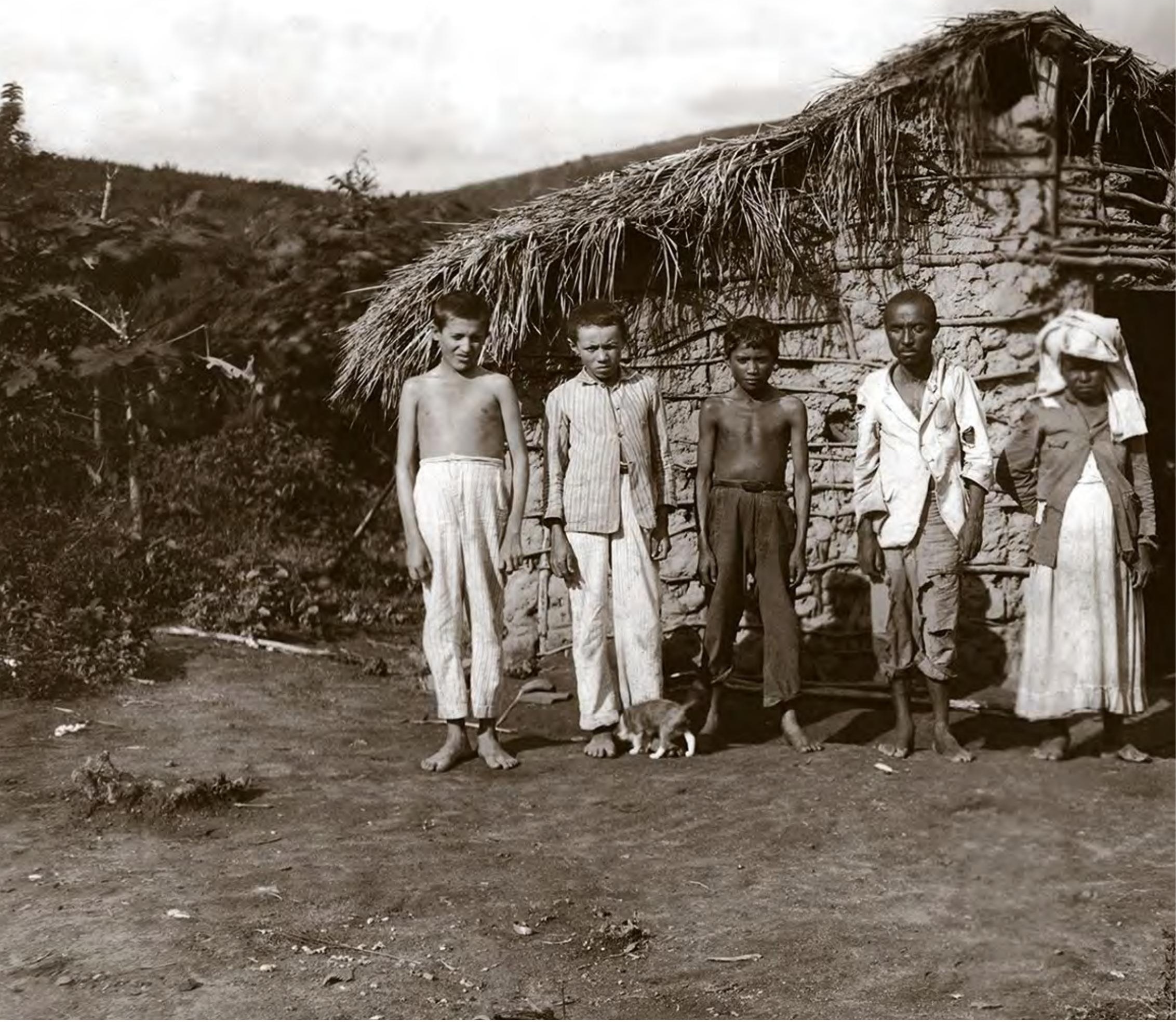

Moradores de Quebrangulo, AL 
Vivendo quatrocentos anos no litoral vastíssimo, em que palejam reflexos da vida civilizada, tivemos de improviso, como herança inesperada, a República. Ascendemos, de chofre, arrebatados na caudal dos ideais modernos, deixando na penumbra secular em que jazem, no âmago do país, um terço da nossa gente. Iludidos por uma civilização de empréstimo; respigando, em faina cega de copistas, tudo o que de melhor existe nos códigos orgânicos de outras nações, tornamos, revolucionariamente, fugindo ao transigir mais ligeiro com as exigências da nossa própria nacionalidade, mais fundo o contraste entre o nosso modo de viver e o daqueles rudes patrícios mais estrangeiros nesta terra do que os imigrantes da Europa. Porque não no-los separa um mar, separam-no-los três séculos...

Euclides da Cunha

After having lived for four hundred years on a vast stretch of seaboard, where we enjoyed the reflections of civilized life, we suddenly came into an unlooked-for inheritance in the form of the Republic. Caught up in the sweep of modern ideas, we abruptly mounted the ladder, leaving behind us in their centuriesold semidarkness a third of our people in the heart of our country. Deluded by a civilization which came to us second hand; rejecting, blind copyists that we were, all that was best in the organic codes of other nations, and shunning, in our revolutionary zeal, the slightest compromise with the exigencies of our own national interests, we merely succeeded in deepening the contrast between our mode of life and that of our rude native sons, who were more alien to us in this land of ours than were the immigrants who came from Europe. For it was not an ocean which separated us from them but three whole centuries... 
Vê-se, muitas vezes, confrangido e alarmado, nas nossas escolas públicas, crianças a bater os dentes com o calafrio das sezões. (...) E isto não nos confins do Brasil, aqui no Distrito Federal, em Guaratiba, Jacarepaguá, na Tijuca... Porque, não nos iludamos, o nosso sertão começa para os lados da Avenida.

Afrânio Peixoto

With distress and alarm, we very often see children's teeth chattering away from the chills of the ague in our public schools. (...) And this is not in the far reaches of Brazil but here in the Federal District, in Guaratiba, Jacarepaguá, Tijuca... For let us have no illusions, the Brazilian hinterlands begin somewhere around [Central] Avenue.

Afrânio Peixoto

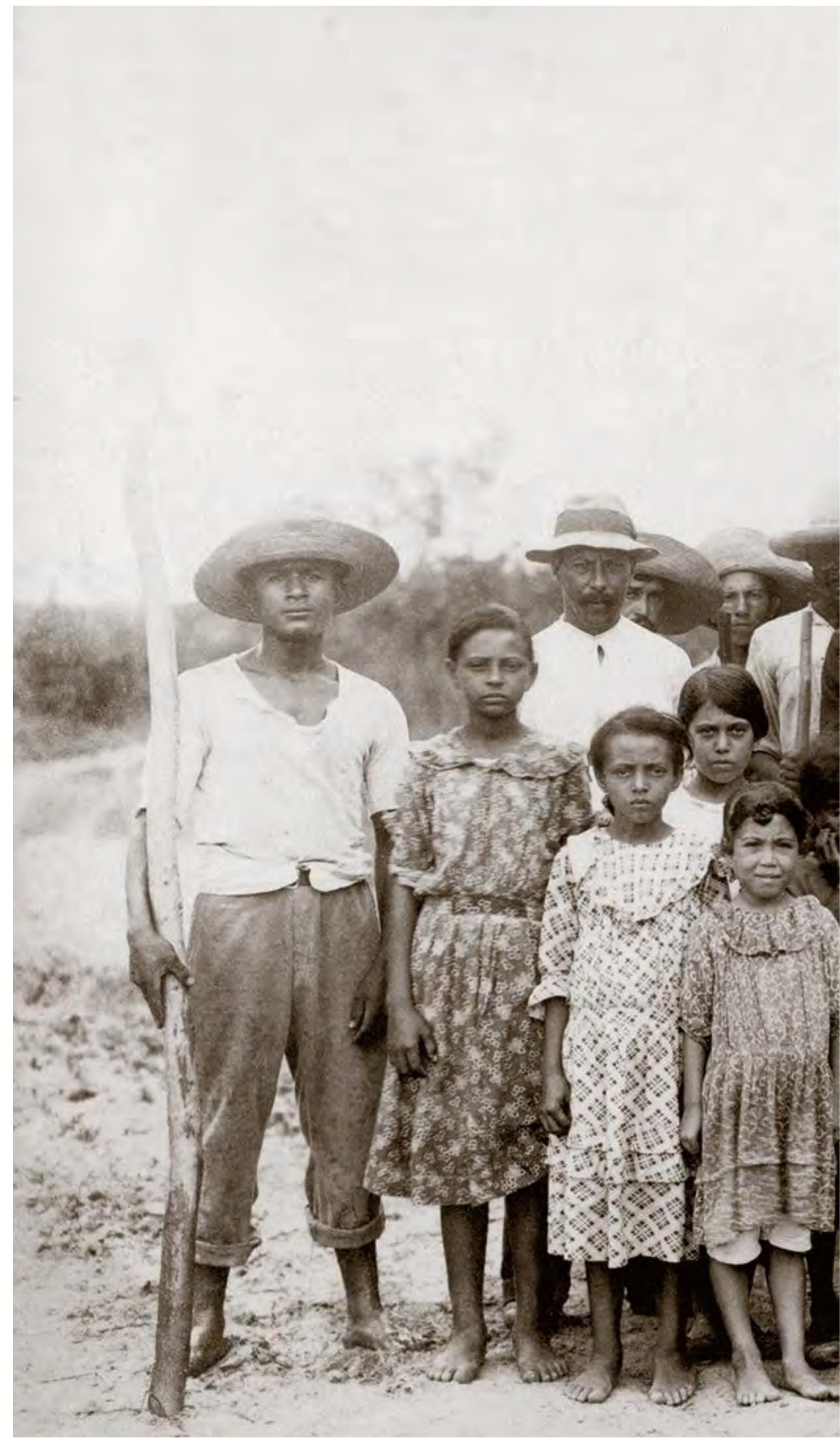

Moradores de área rural do estado do Rio de Janeiro

Foto A. Cerqueira

Acervo Casa de Oswaldo Cruz

Residents from rural Rio de Janeiro

Photograph by A. Cerqueira 


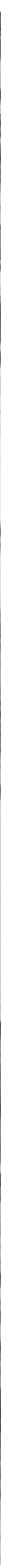



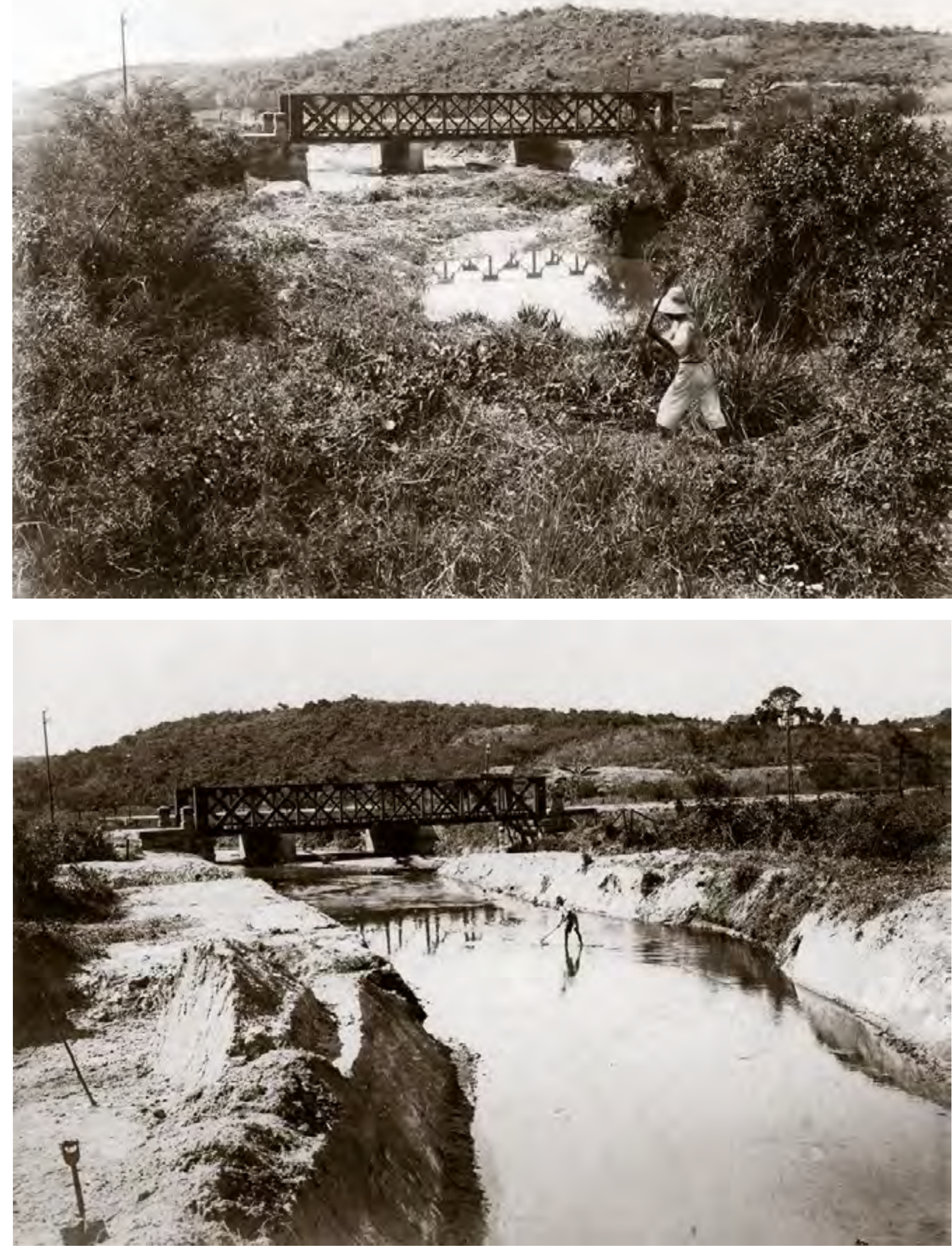

Obra de engenharia sanitária em Honório Gurgel, no Rio de Janeiro Acervo Casa de Oswaldo Cruz

Sanitary engineering works in the neighborhood of Honório Gurgel, Rio de Janeiro

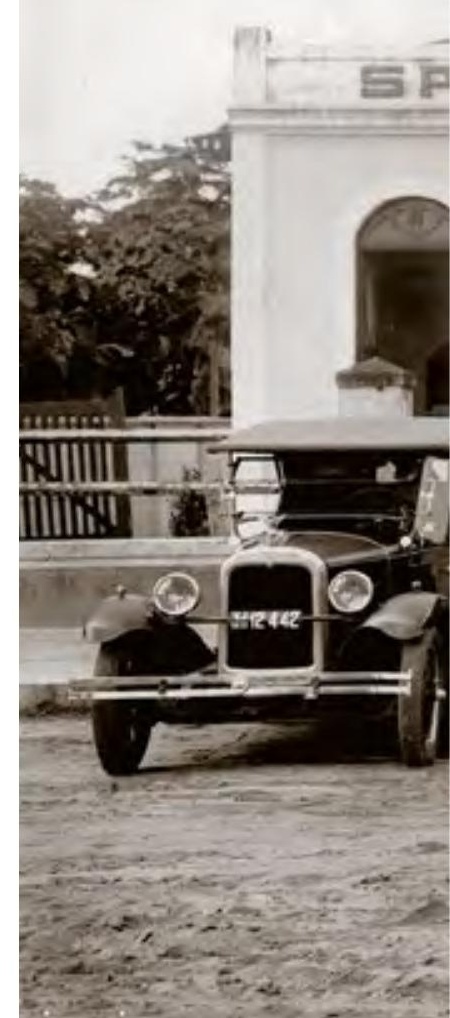



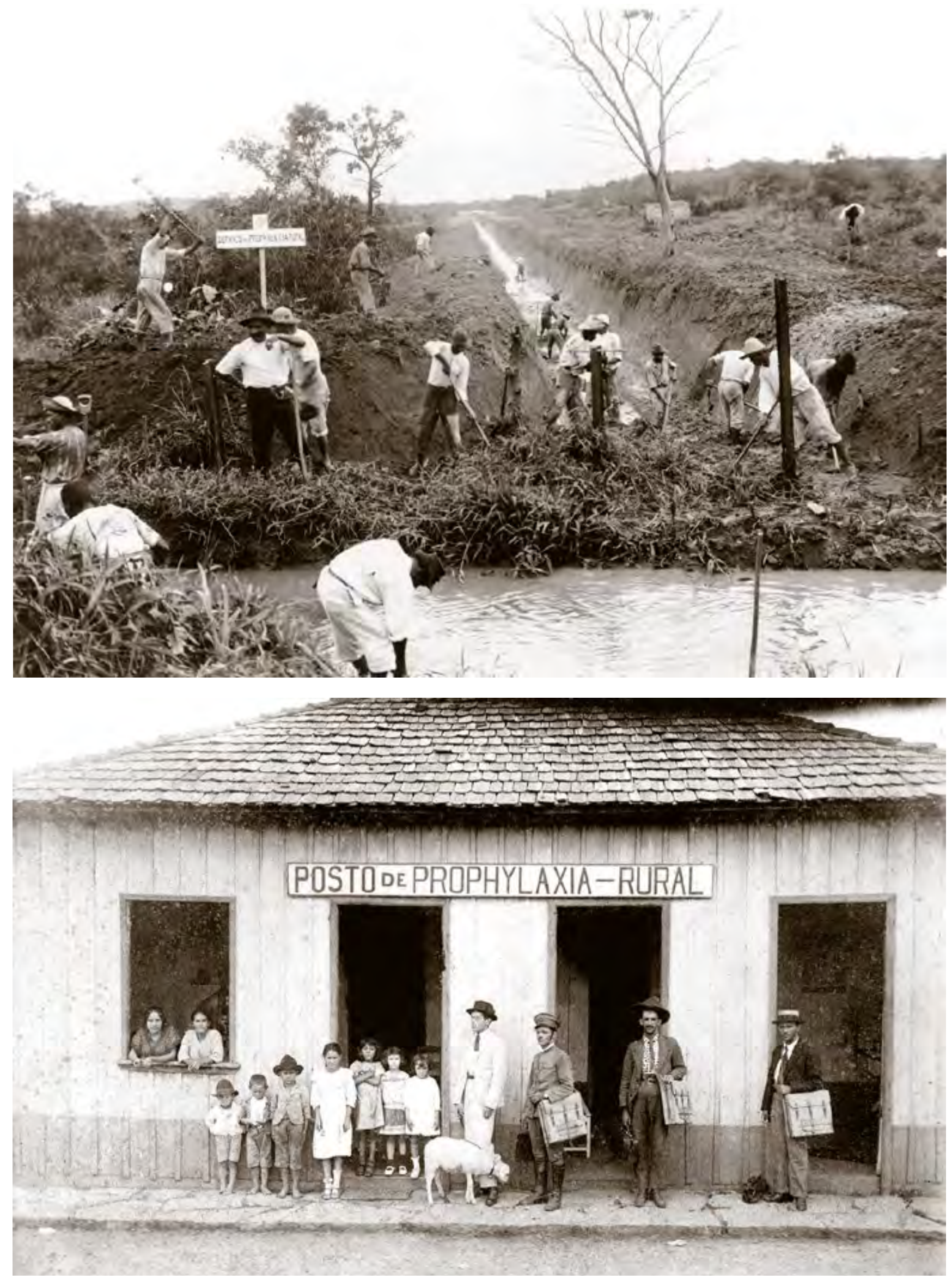

Obra de engenharia sanitária em Ribeirão Cachoeira.

Mesquita, RJ, 10 nov. 1922

Acervo Casa de Oswaldo Cruz

Sanitary engineering works in Ribeirão Cachoeira.

Mesquita, Rio de Janeiro, Nov. 10, 1922

Posto sanitário de Colônia Mineira, atual Siqueira

Campos, PR, 10 maio 1922

Acervo Casa de Oswaldo Cruz

Sanitary post in Colônia Mineira, now Siqueira Campos,

Paraná, May 10, 1922 

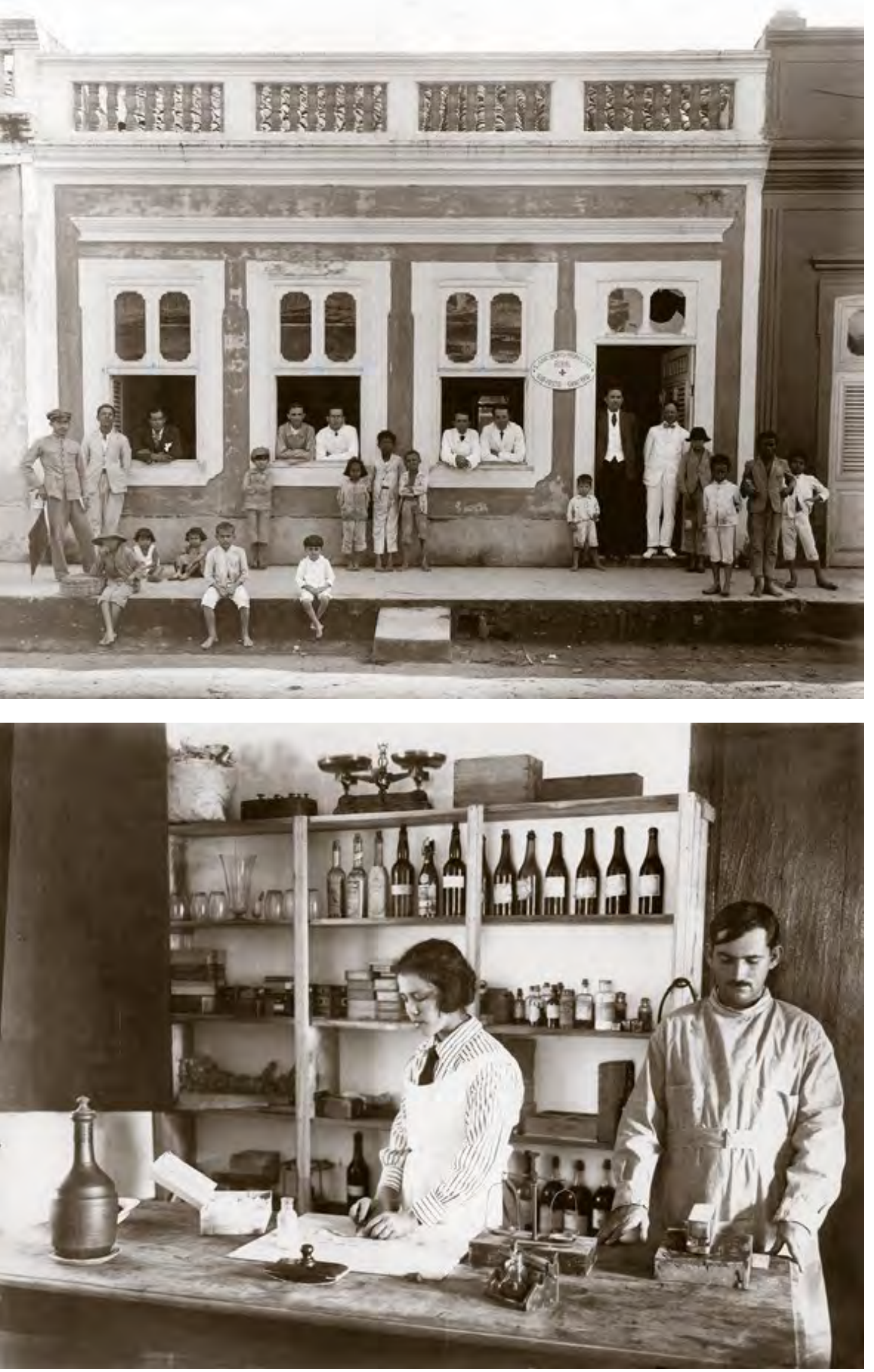

Subposto sanitário de Pilar, PB Acervo Casa de Oswaldo Cruz

Pilar sanitary sub-post, Paraíba

Com sincero regozijo e bem fundadas esperanças, hoje poderemos anunciar a organização de serviços sanitários rurais em onze Estados da União, de acordo com a nova lei federal. E temos a segurança de que algumas das unidades federadas, ainda excluídas desses serviços, embora realizando trabalhos de saneamento por iniciativa própria, ou auxiliados pela 'Rockefeller Foundation', não custarão em vir ao encontro de nossos intuitos e concorrerem para o êxito maior dessa obra de redenção sanitária do Brasil, que deve estender-se, com unidade de vistas e solidariedade de intuitos, a todo território nacional.

Carlos Chagas

With sincere rejoicing and justifiable hope, today we can announce the organization of rural sanitary services in eleven States of the Union, pursuant to new federal law. And we are certain that it will not be long before some states and other units of our federation as yet excluded from these services, albeit undertaking sanitation works at their own initiative or with the assistance of the Rockefeller Foundation, will not tardy in joining us in our purpose and contribute to the greater success of this endeavor to achieve the sanitary redemption of Brazil, which should extend throughout all our national territory, with a shared vision and unity of purpose.

Carlos Chagas

Farmácia do posto sanitário de Quebrangulo, AL Acervo Casa de Oswaldo Cruz

Quebrangulo sanitary post pharmacy, Alagoas 


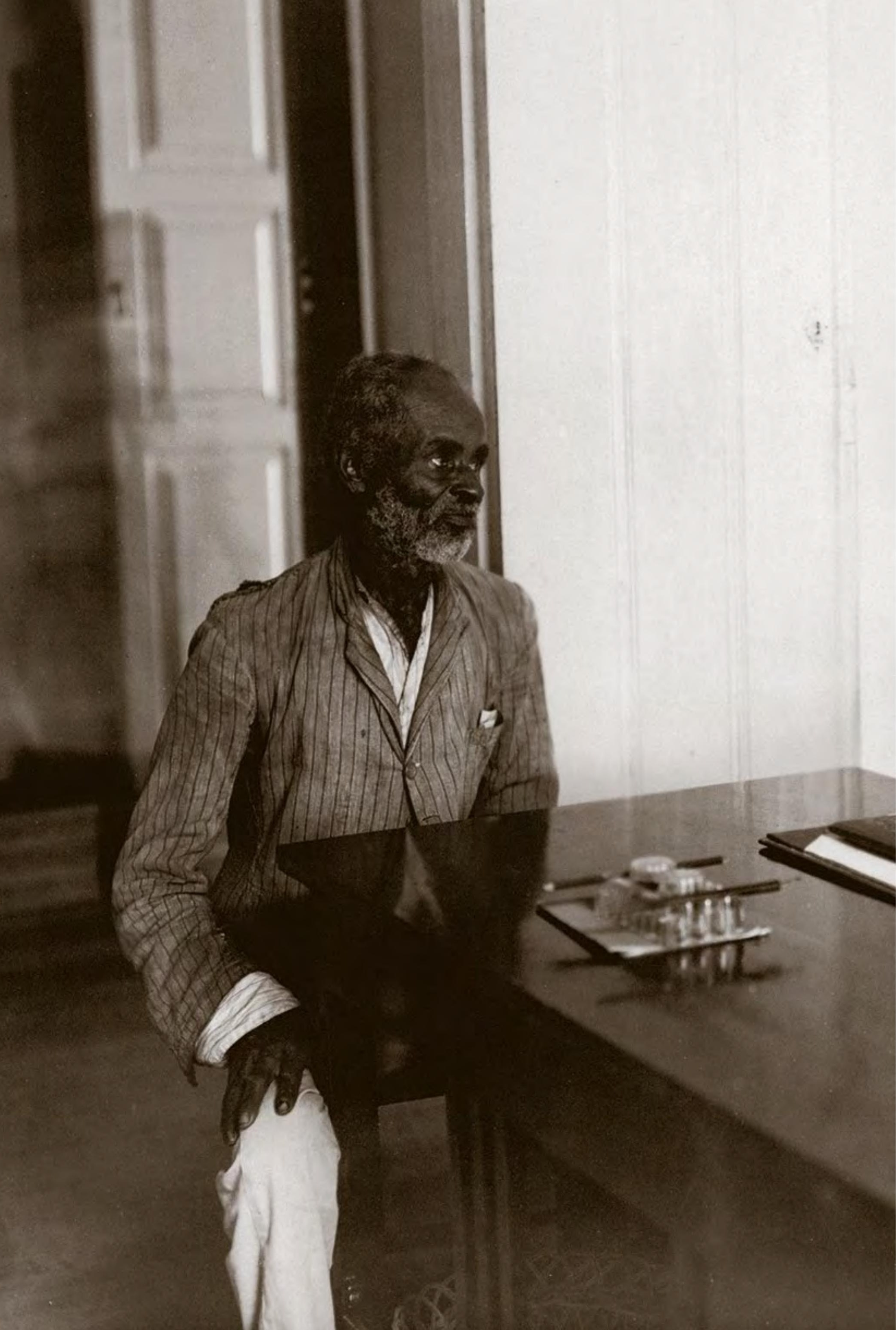


Atendimento médico no posto sanitário de Barra do Camaragibe, AL

Acervo Casa de Oswaldo Cruz

Health care at a sanitary

post in Barra do

Camaragibe, Alagoas 

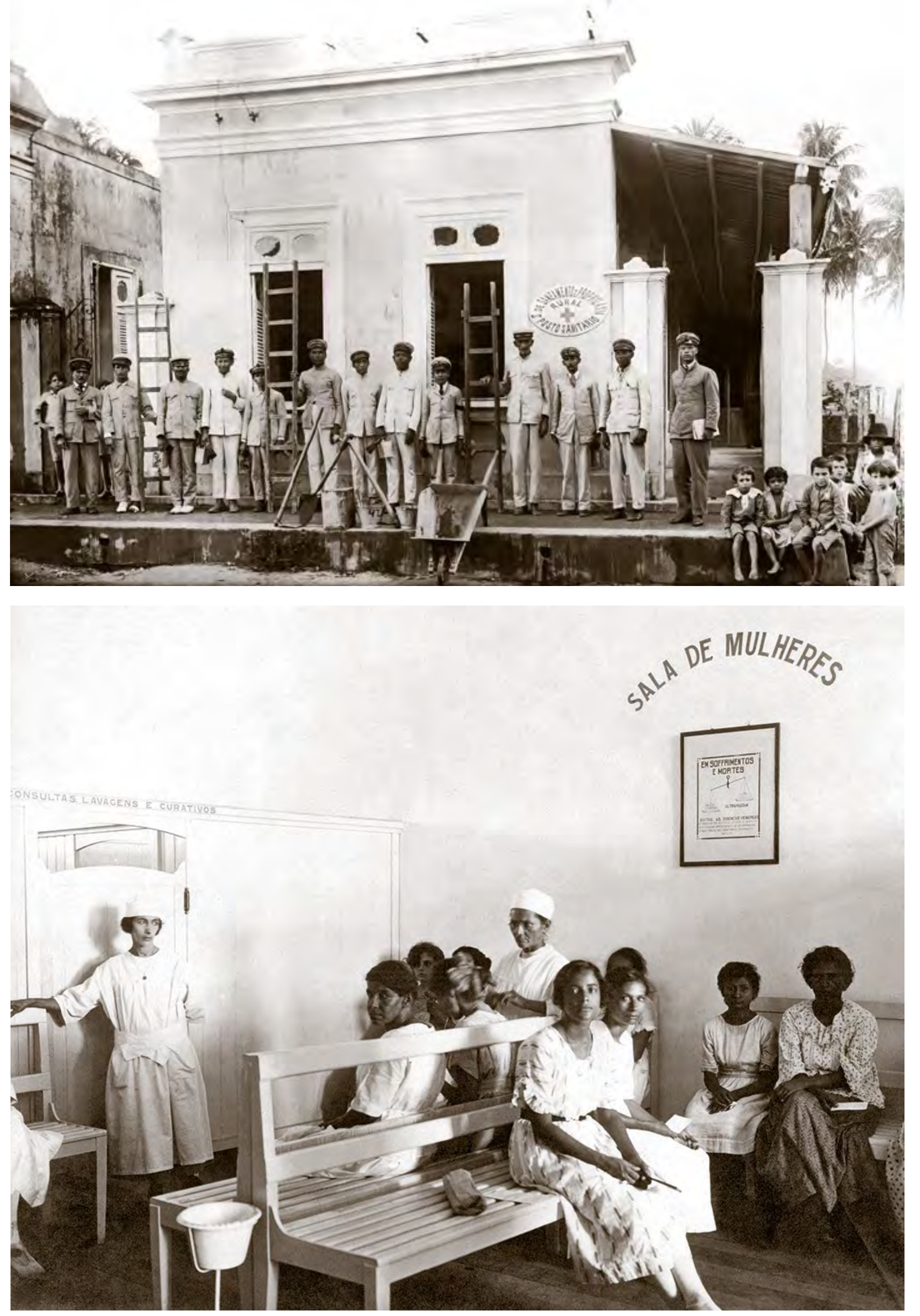

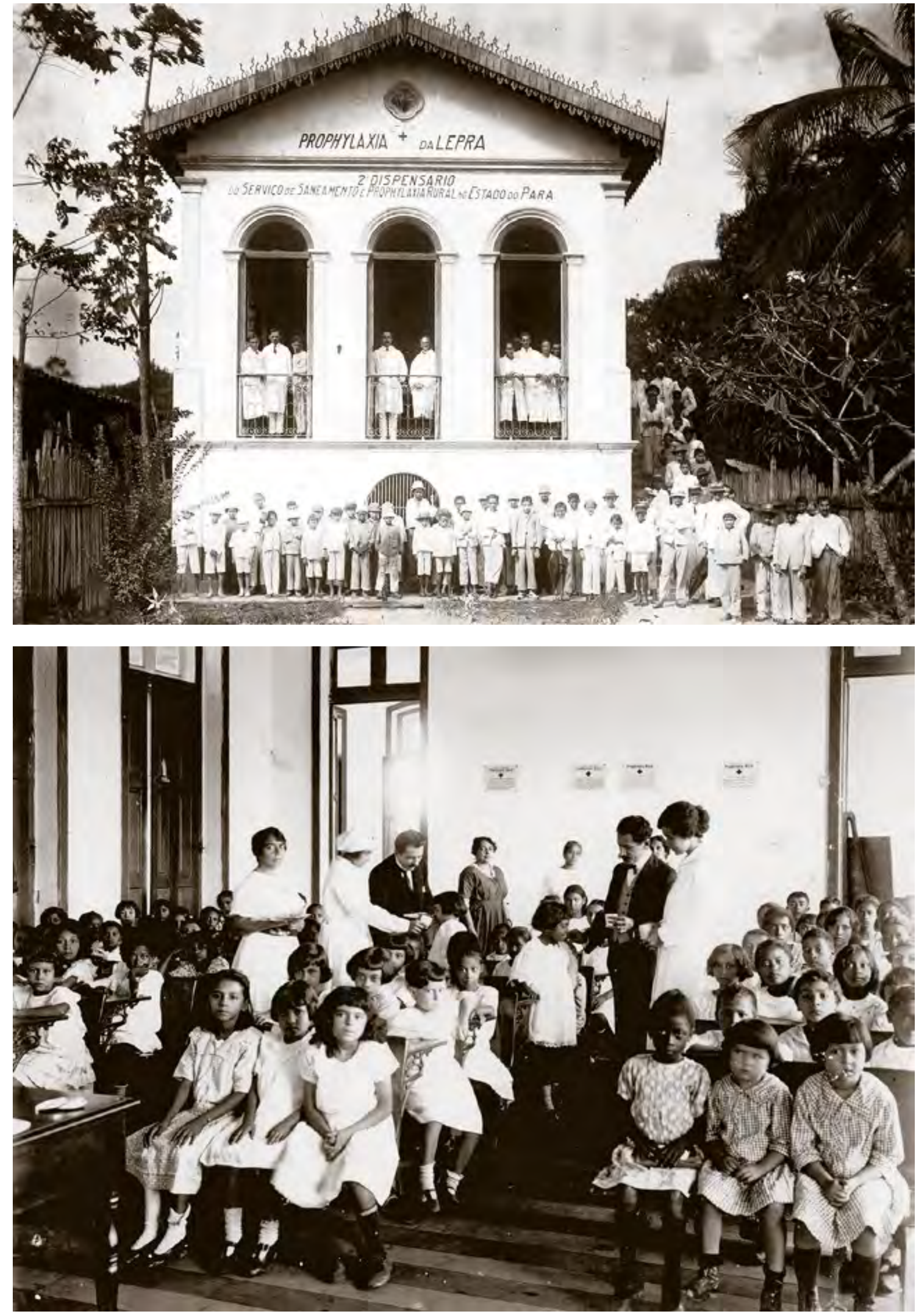

Dispensário do Serviço de Saneamento e

Profilaxia Rural do Pará Acervo Casa de Oswaldo Cruz

Dispensary at the state of Pará's Rural

Sanitation and

Prophylaxis Service

Administração de quinina a alunos de grupo escolar no

Amazonas. Ao fundo, de termo escuro, Samuel Uchôa, chefe do Serviço de

Saneamento e Profilaxia Rural do Amazonas

Acervo Casa de Oswaldo Cruz

Giving quinine to school students in Amazonas. In back, in a dark suit, Samuel Uchôa, head of the Rural Sanitation and Prophylaxis Service of Amazonas
Livreto de divulgação produzido pelo Departamento

Nacional de Saúde

Pública sobre

a formação de enfermeiras. Rio de

Janeiro, 1921

Acervo Casa de Oswaldo Cruz

Recruiting booklet about nursing

education, put out by the National

Department of Public Health. Rio de Janeiro, 1921 


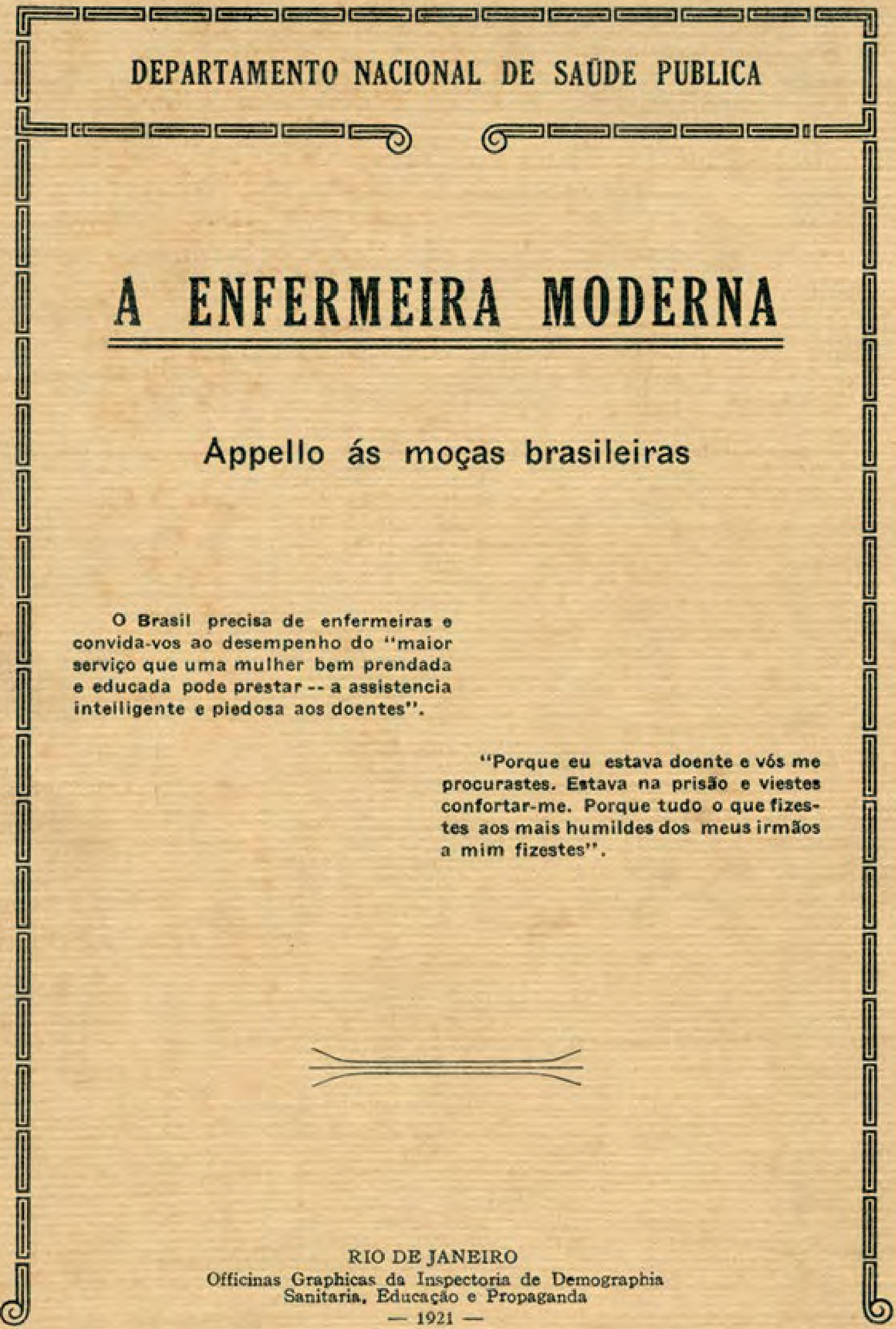




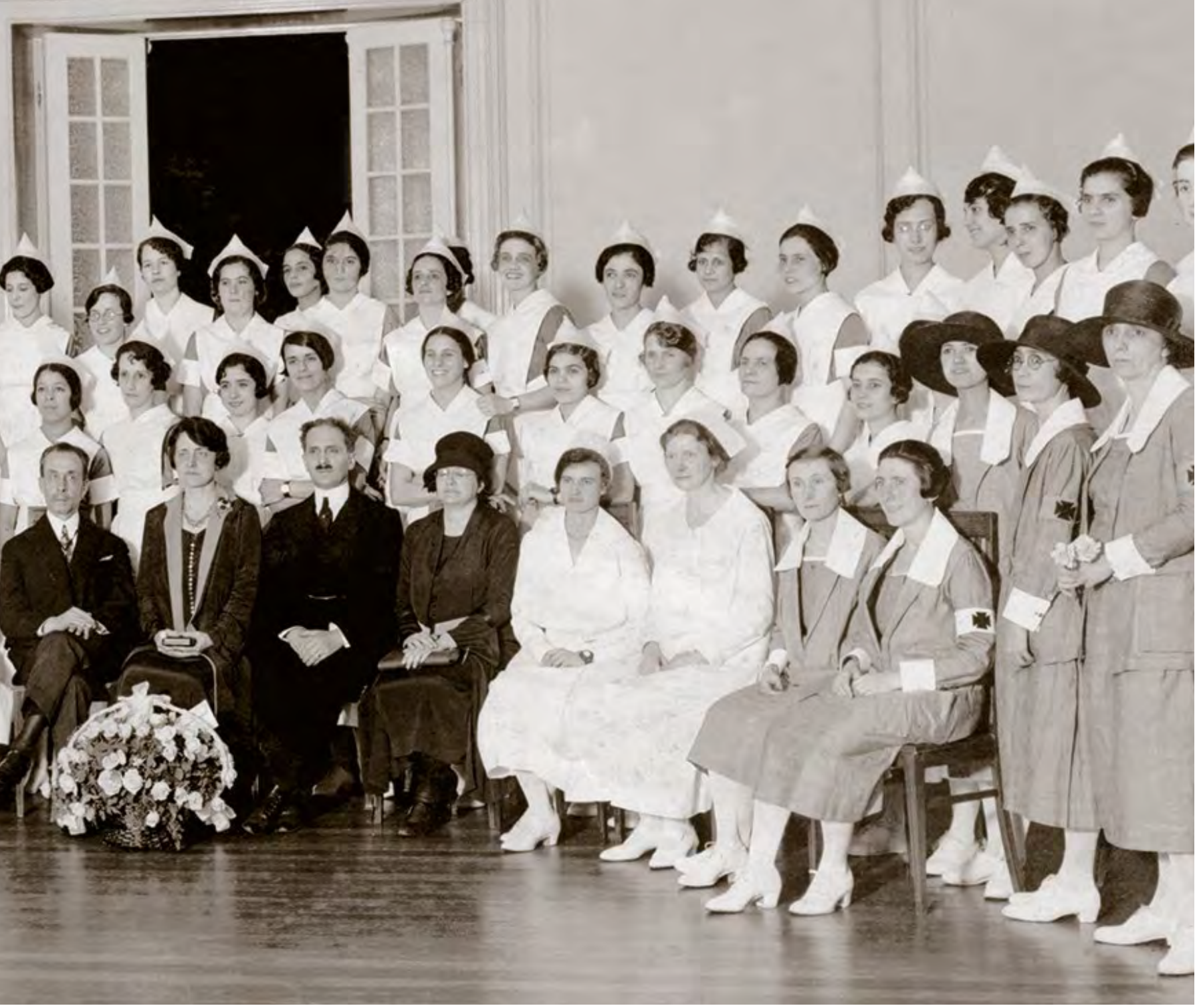

Chagas na inauguração do internato da Escola de Enfermagem Anna Nery. A sua esquerda, a

superintendente geral

do Serviço de

Enfermeiras do

Departamento Naciona

de Saúde Pública, a

norte-americana Ethel

Parsons, e Raul Leitão

da Cunha, professor da

Escola de Enfermagem.

Rio de Janeiro, 29 jul.

1926

Acervo Casa de Oswaldo

Cruz

Chagas at the

inauguration of the

Anna Nery Nursing

School student

dormitory. To his left,

Ethel Parsons (from the

U.S.), then

superintendent

general of the Nationa

Department of Public

Health's Nursing

Service, and Raul Leitão

da Cunha, professor at

the Nursing School. Rio

de Janeiro, Jul. 29, 1926

Alunas da Escola de

Enfermagem Anna Nery

em aula de microbiologia

Acervo Casa de Oswaldo Cruz

Students in a

microbiology class at

the Anna Nery Nursing

School

Alunas da Escola de

Enfermagem Anna Nery

realizam curativos em

paciente sob a

supervisão da

enfermeira chefe Miss

Murray

Acervo Escola de

Enfermagem Anna Nery

Students at the Ann

Nery Nursing School,

placing dressings on a

patient under the

supervision of chief

nurse "Miss Murray" 
Na profilaxia da tuberculose encontramos outro exemplo valioso da atividade das enfermeiras visitadoras. Aí, mais do que em qualquer outro ramo da administração sanitária, sua função é preponderante e

imprescindivel. São elas que levam aos tuberculosos toda a educação técnica necessária a impedir a difusão do contágio, cabendo-lhes no caso, a alta responsabilidade de evitar pelos ensinamentos acertados a contaminação das pessoas que assistem carinhosamente os tuberculosos, e às quais faltam as mais das vezes as noções mais elementares relativas ao contágio da peste branca.

O Jornal, 1922

We find another valuable example of the work of visiting nurses in tuberculosis prophylaxis. Here more than in any other branch of sanitary management, their role is crucial and indispensable. They are the ones who provide tuberculosis sufferers with all the technical education needed to keep the contagion from spreading, entrusted here with the immense responsibility of preventing, through proper teaching, the contamination of the people who tenderly care for tuberculosis patients, [people] who more often than not lack the most basic notions about the contagion of the white plague.

O Jornal, 1922

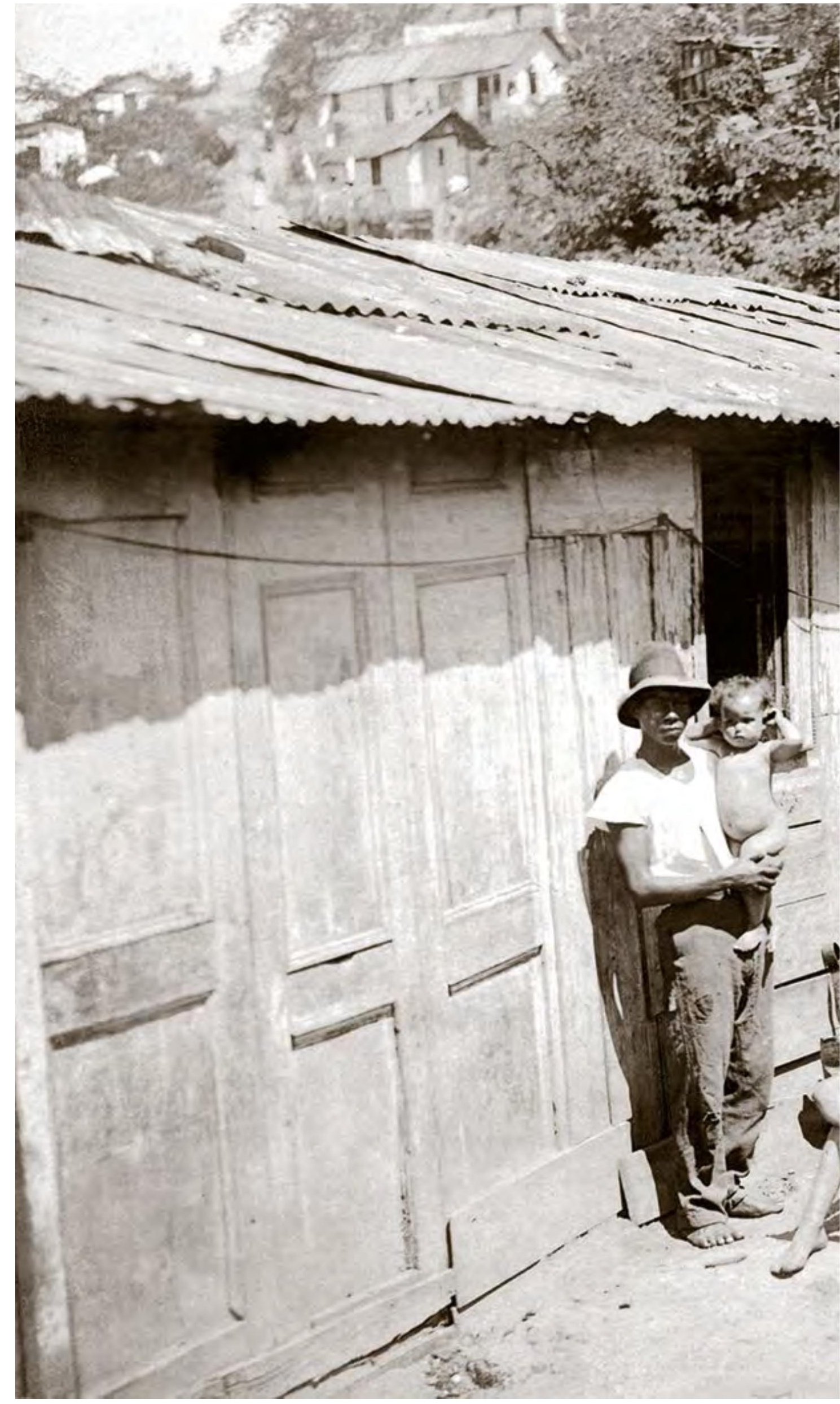

Enfermeira visitadora da Inspetoria de Profilaxia da Tuberculose em favela na cidade do Rio de Janeiro, final da década de 1920 Acervo Casa de Oswaldo Cruz

Visiting nurse from the Tuberculosis

Prophylaxis Inspectorship in a Rio de Janeiro slum, late 1920 s 


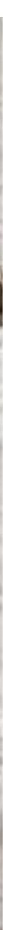

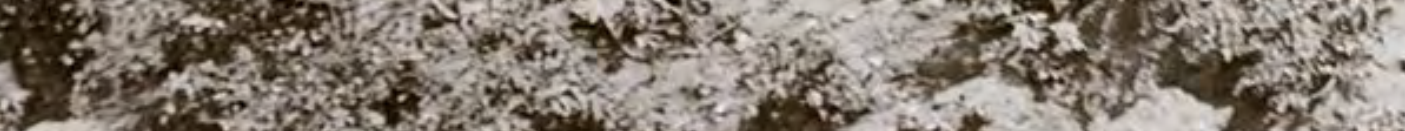

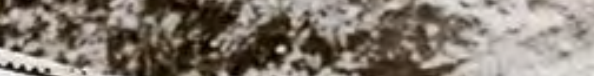

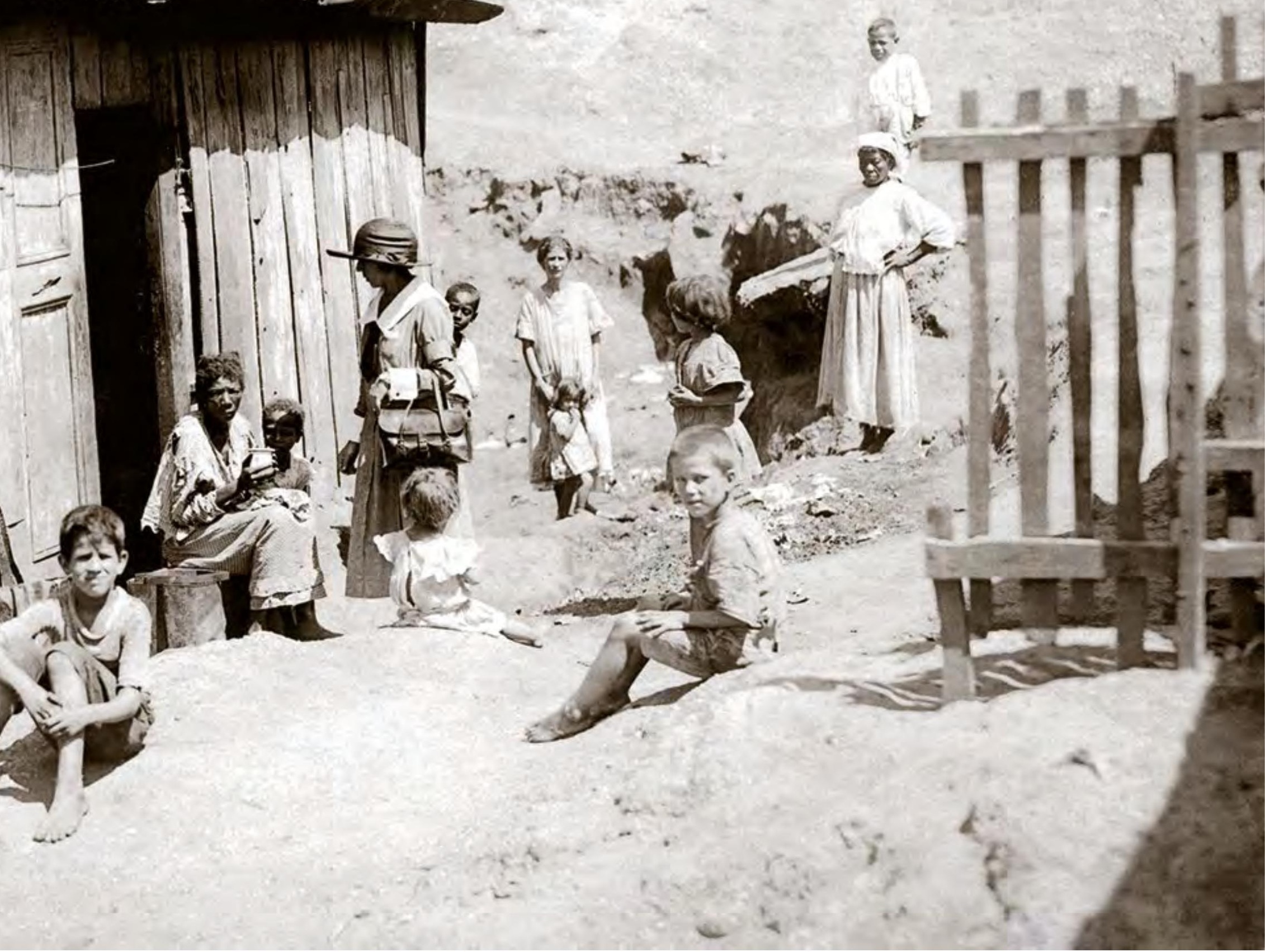




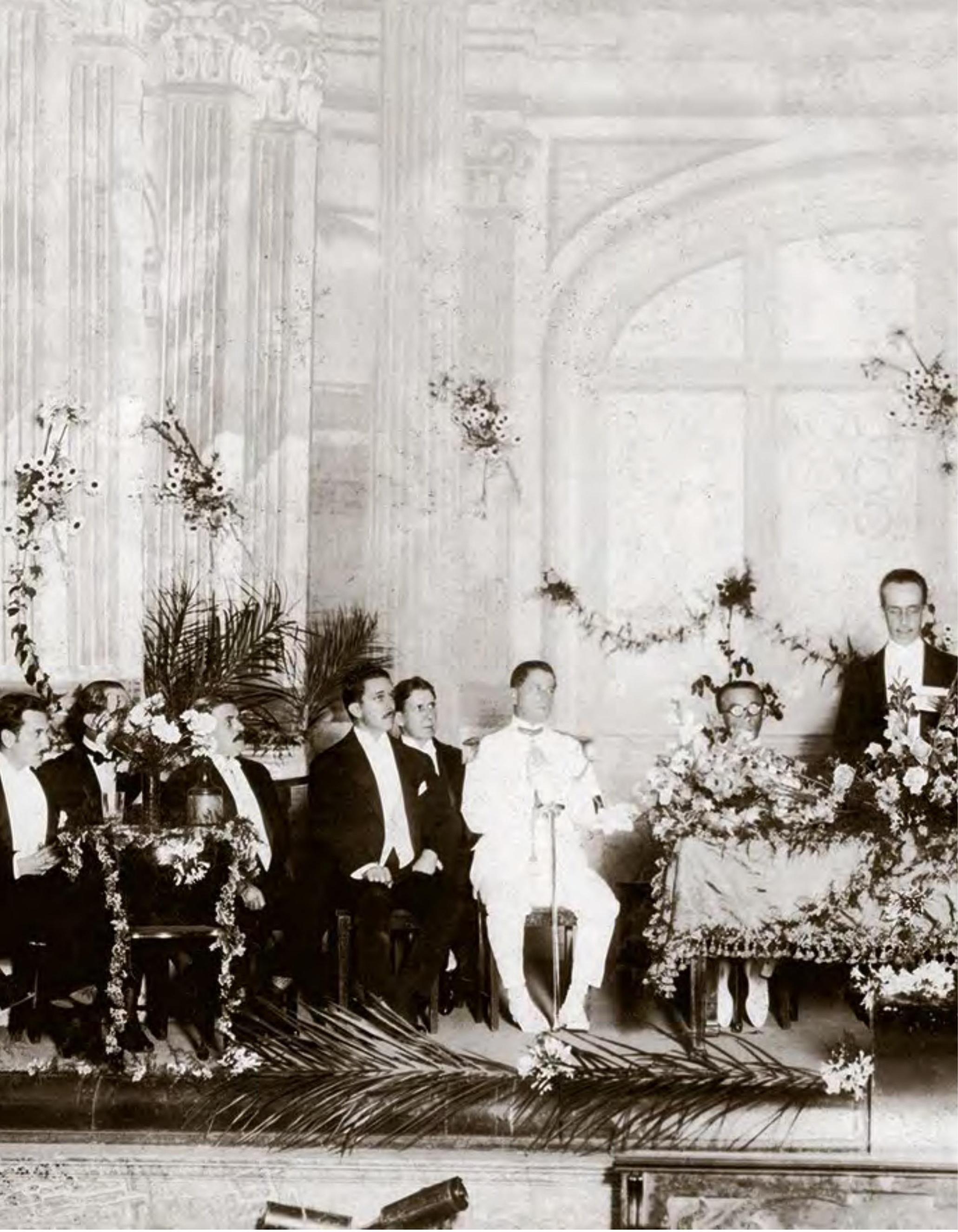




\section{E CHOVA ARROZ...}

A proposito da ficada do Dr. Carlos Chagas no D. N. S. P. :
Estará desmerecendo a fama de Manguinhos?

\section{Alastra-se a variola apezar da vaccina}

Ha medicos que reclamam contra a inefficacia daquelle recurso official

Mexa-se e fale, Sr. Dr. Carlos Chagas

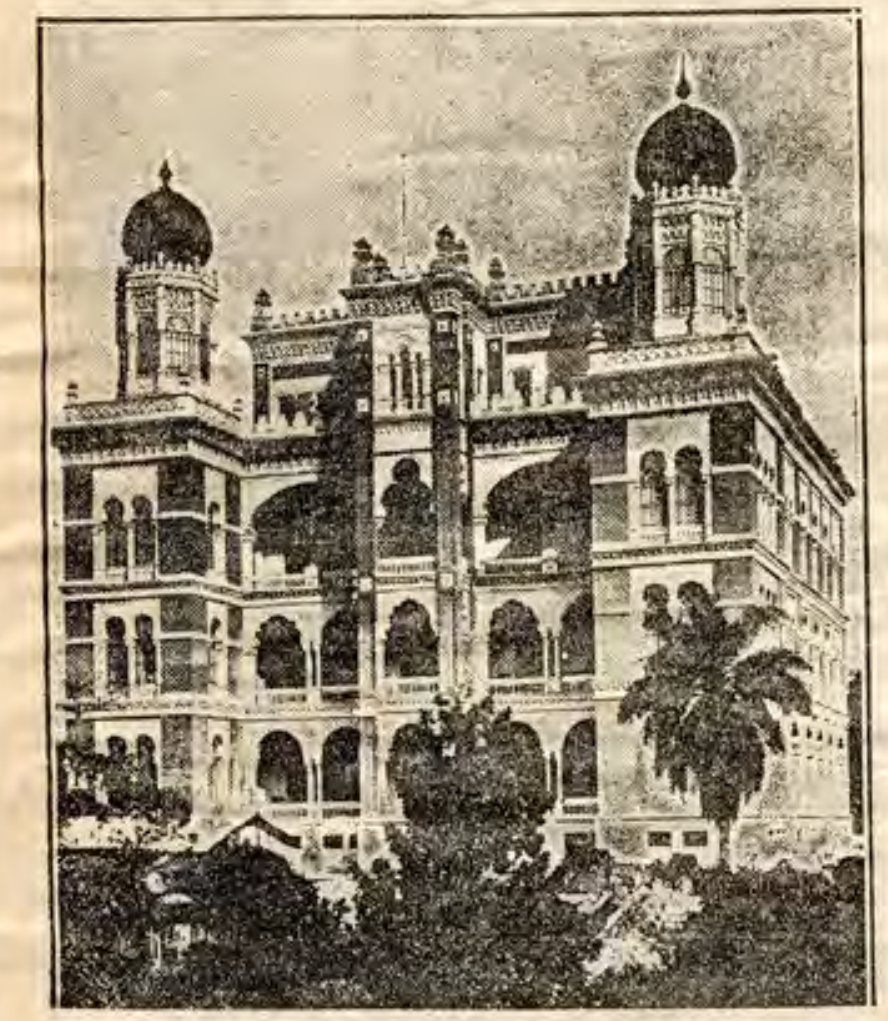

Instituto 0swaldo Cruz

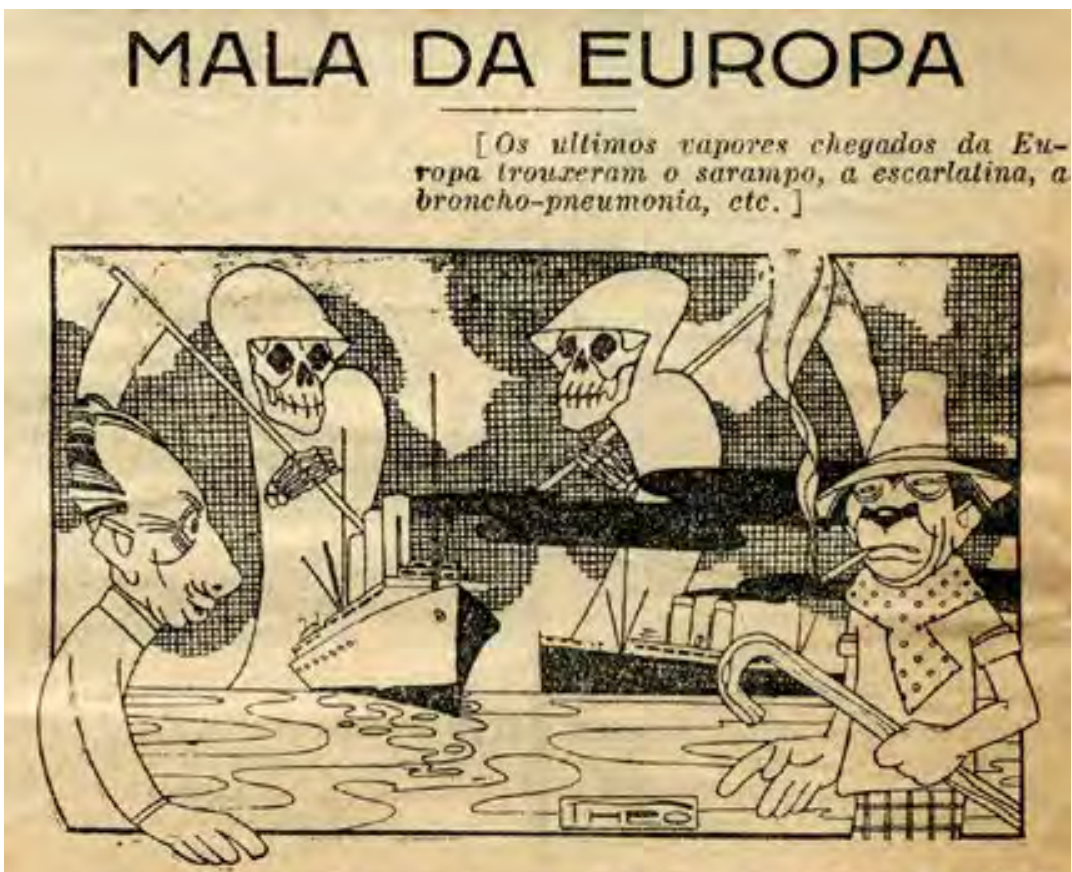

CHAGAS - Nāo vês aquelles navios? Trazem jornaes e revistas cheios de referencias ao men nome e aos mens titulos..

JEGA - Parece que trazem mais alguma cousa seo dinuto!...

Estará desmerecendo a fama de Manguinhos?

O Globo, 29 mar. 1926

Acervo Casa de Oswaldo Cruz

"Is Manguinhos's renown being disparaged?"

O Globo, Mar. 29, 1926

Mala da Europa

O Globo, 7 abr. 1926

Charge de Theo

Acervo Casa de Oswaldo Cruz

"Baggage from Europe"

O Globo, Apr. 7, 1926

Cartoon by Theo chova arroz...

OMalho, 24 nov. 1923

Charge alusiva ao

pedido de exoneração

do cargo de diretor do

Departamento Nacional

de Saúde Pública, feito

por Chagas em fevereiro de 1923, e recusado pelo presidente Arthur Bernardes

Charge de J. Carlos (José Carlos de Brito e Cunha, 1884-1950)

Acervo Fundação Biblioteca Nacional

"And it rains manna..."

O Malho, Nov. 24, 1923

Cartoon referring to

Chagas's request to step down as director of the

National Department of Public Health, lodged in

February 1923 and

rejected by Brazilian president Arthur Bernardes

Cartoon by J. Carlos 


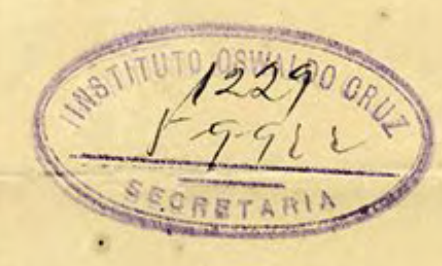

Sir,

I have the honour to inform you that the Council of the league of Nations, at the session recently held in Iond on, approved your nomination as member of the Health Committee. From the wires exchanged between you and the hedical Director, I am pleased to see that you have already expressed your wilingness to serve on the Committee.

hay I add that the next meeting of the Health Committee will take place on August 14th, when your colleagues will be pleased to welcome their new member.

I have the honour to be,

Sir,

Your obedient servant,

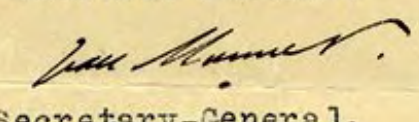

Deputy Secretary-General.

Dr. Carlos Chagas,

Director of the

Oswald Cruz Institute, RIO DE JANEIRO. 


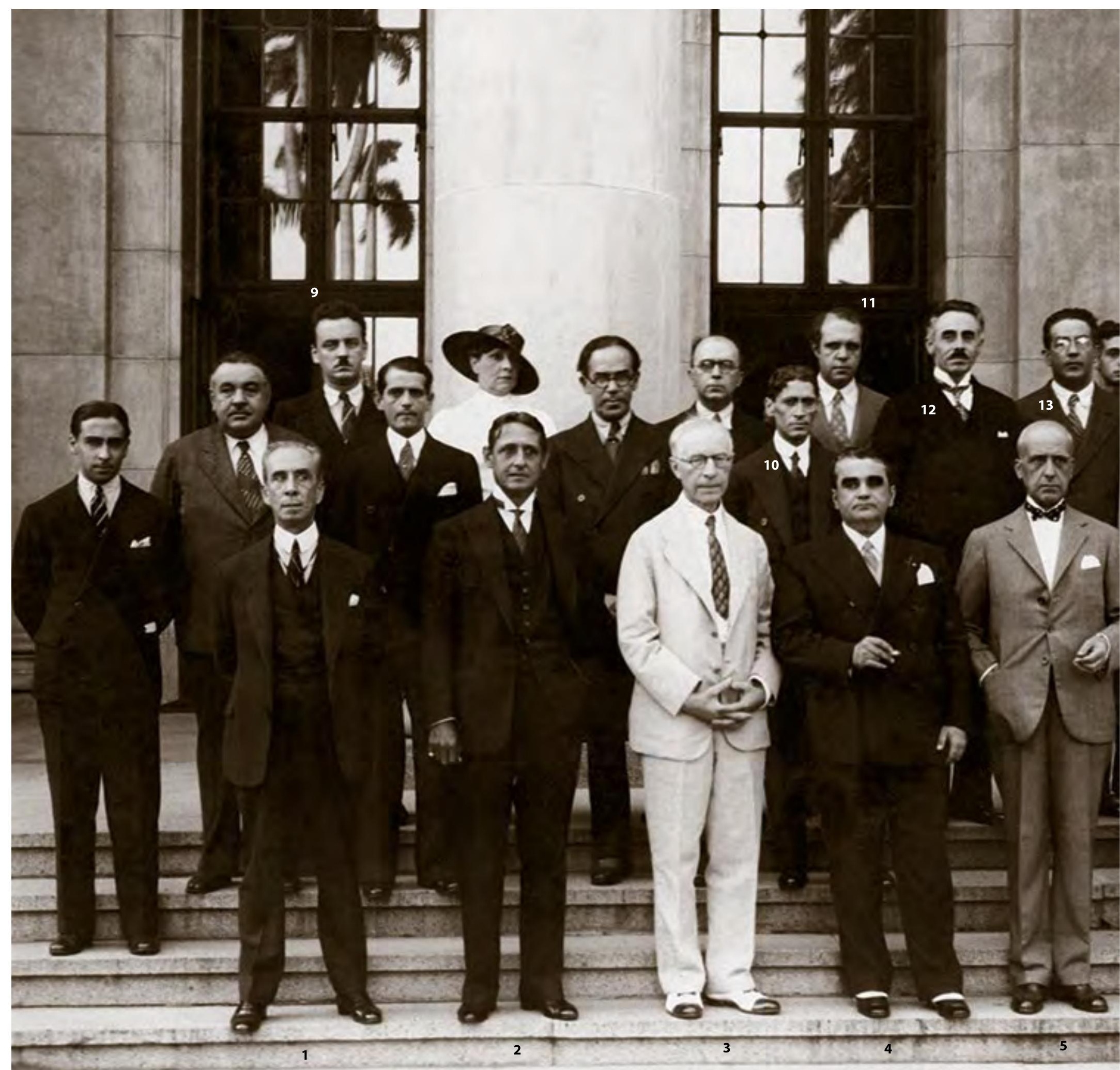

Inauguração do Centro Internacional de Leprologia

1 - Carlos Chagas; 2 - Guilherme Guinle; 3 - Etienne Burnet, representante da Sociedade das Nações; 4 - Washington Pires,

ministro da Educação e Saúde; 5 - Felix Barros Cavalcante de Lacerda, ministro das Relações Exteriores; 6 - Raul de Almeida

Magalhães; 7 - Eduardo Rabello; 8 - Oscar Silva de Araújo; 9 - Evandro Chagas; 10 - José Carneiro Felippe; 11 - Phocion Serpa;

12 - Heráclides César de Souza-Araújo; 13 - José da Costa Cruz; 14 - Clementino Fraga

Rio de Janeiro, 24 abr. 1934

Acervo Casa de Oswaldo Cruz

Inauguration of the International Leprology Center

1 - Carlos Chagas; 2 - Guilherme Guinle; 3 - Etienne Burnet, representing the Society of Nations; 4 - Education and Health

Minister Washington Pires; 5 - Foreign Affairs Minister Felix Barros Cavalcante de Lacerda; 6 - Raul de Almeida Magalhães;

7 - Eduardo Rabello; 8 - Oscar Silva de Araújo; 9 - Evandro Chagas; 10 - José Carneiro Felippe; 11 - Phocion Serpa; 12 - Heráclides

César de Souza-Araújo; 13 - José da Costa Cruz; 14 - Clementino Fraga

Rio de Janeiro, Apr. 24, 1934 


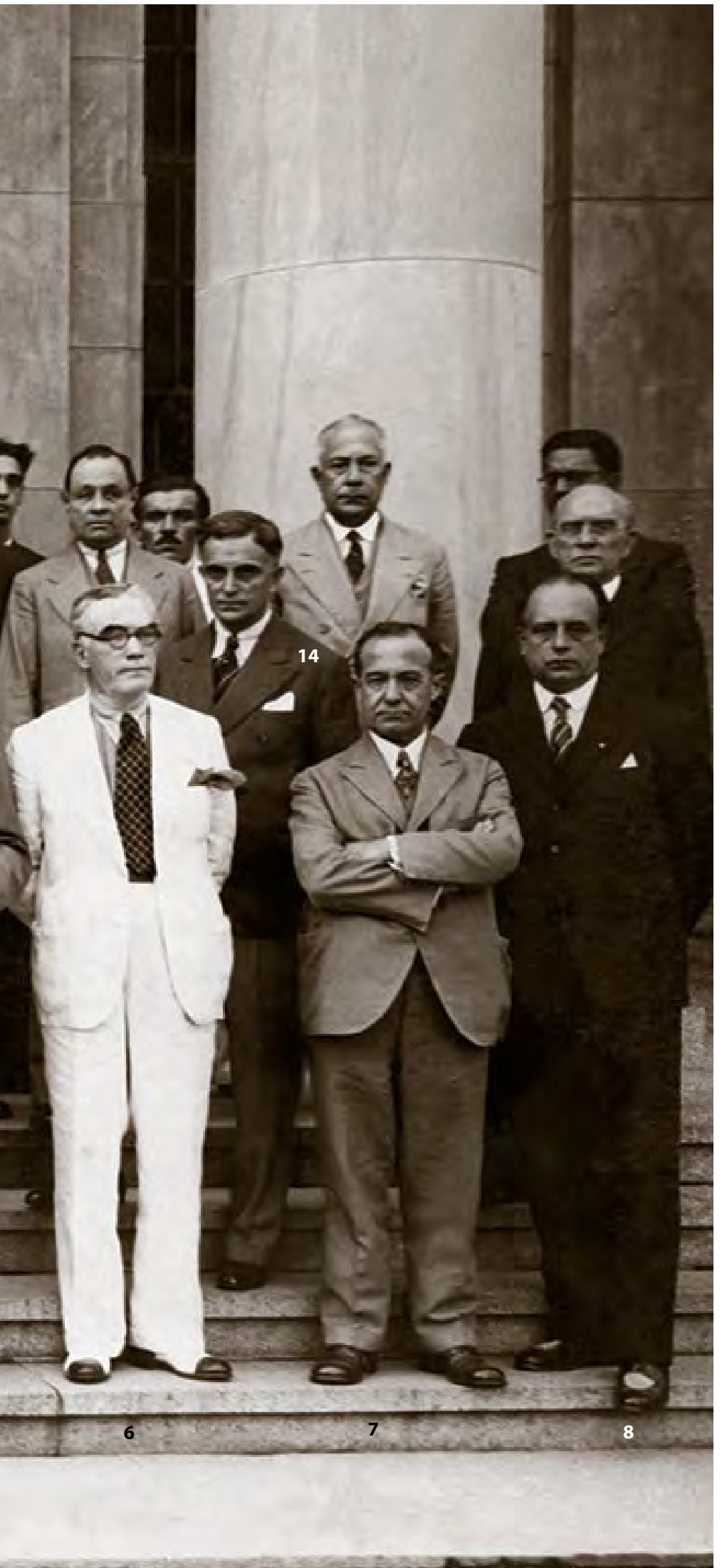

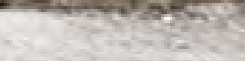

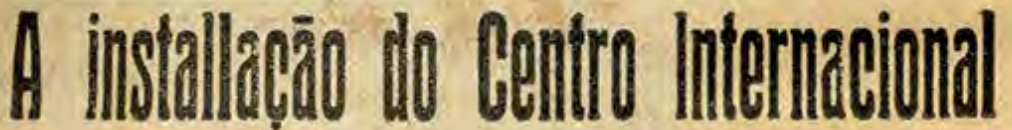 te bentobyja no Birsil \\ Fala á NOITE, sobre a missão desse instituto scientifico, o professor Carlos Chagas}

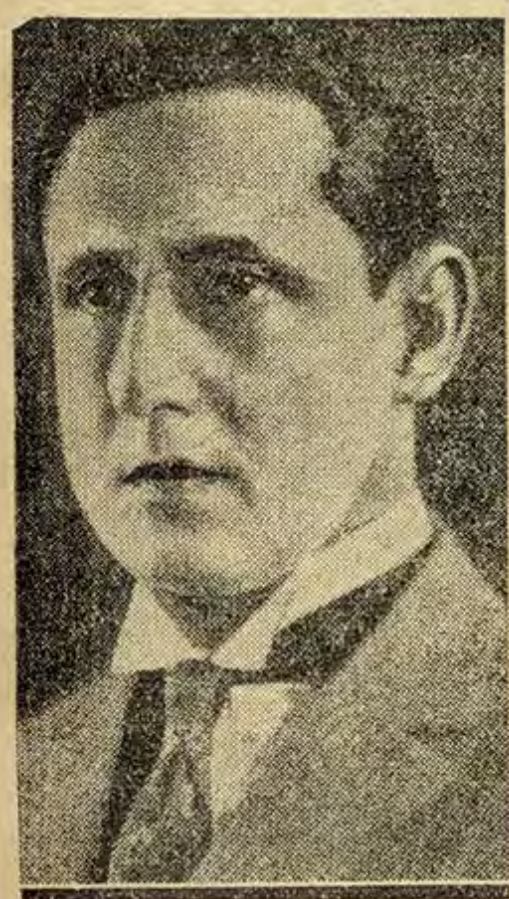

Sr. Guilherme Guinte

0 Centro Internacional de Lepro logia que vae ser installado em nosso paiz representa, inquestionavelmente, uma iniciativa de extraordinario relevo, cujos resultados interessam por egual a todos os povos. O problem da lepra tem constítuido, através do seculos, um problema gravissimo e uma preoccupaço permanente para o mundo scientifico. Pouco se tem conseguido, por emquanto, no sentido da repressáo ao mal de Hansen, dada precariedade dos processos preventidade continua desse, modo, a propagar-se de maneira impressionante. Emprehende-se, agora, um largo plaEmprehende-se, agora, um largo plano de estudos e pesquisas scientificas, como jamais fora antes levado a
effeito, com a creacåo do Centro Ineffeito, com a creaçăo do Centro Internacional de Leprologia, cuja direeção foi confiada, merceidamente, ao sabio brasileiro, professor Carlos Chagas. Figura eminente, enja palavra é acatada no mundo inteiro, tem - professor Carlos Chagas, na direeção do Instituto de Manguinhos, augmentado consideravelmente o patrimonio scientifico que Oswaldo Cruz nos legou, realisando uma obra notavel que honra eleva a cultura notavel que honra e eleva a cultura
medica brasileira. Ninguem melhor do que elle poderia, portanto, ser indicado para o alto posto que lhe confiou instituto de Genebra Ouvido per pela NOITE, o professor Carlos Chagas accentuou a importancia da funprologia o definiu os seus objectivos. A lepra no Brasil e no mundo

- 0 Centro Internacional de Leprologia - declara o entrovistado tem alta finalidade medico-social e autorisa, no programma de trabalhos que vae realisar, largas perspectivas de aperfeiçoamento technico nos dominios da medicina preventiva.

Duas razōes primordiaes fundamentam essa iniciativa e tornam digna de encomios a decisăo do governo brasileiro $\mathrm{Em}$ primeiro logar, a importancia maxima do problema da le pora, ño so para o nosso paiz, náo só pra, ná so para o nosso paiz, nắo só para o continente americano, senáo ainda para o mundo inteiro; $\mathrm{em}$ segundo logar, e como razá tambem ponderavel, as numerosas ineognitas que perduram nesse capitulo da pathologia humana, e difficuitam as providencias sanitarias e impossibilitam n exito definitivo do methodo prophylactico.

Nảo ficamos Iongo da verdade apreciando em 30 mil a cifrs de leprosos de Brasil e em 120.000 o numero desses infelizes, sb me continente sul-americano $B$ nas. Indias Inglezas existem mais de um millhão e 500 mil leprosos, no Japáo approximadamente 20 mì e Indias Hollandexas, nas colonias tropicaes de diversas naçóes da Europa, em vastas regióes do Extremo Oriente, é elevado o indice endemico. Mais ó que o contagio, embnra de modo iento, vae sempre se diffundindo, como $\&$ evidencia o ausmento prozressivo de enfermos, com o spparecimento de novos f $8 \mathrm{cos}$, entro nós, na Republica Argentina, na Colombia Republica Arcentina, na coutormbia em outros paizes. Por outro lado, aproveitados na lith contra esse dinença os processos actuaes de prevençáo. ermesmo applicatios com o maximo do conseguidos.

Os processos de combate

- O isolamento em leprosarios, ou n segrezacão de leprosos em colonias a segresaça de lejer sistencia medico-social, de accordo com as exigencias da technica moderua com os sentimentos de piedade, esse isolamento, de certo a medida de maior efficacia absolutamente indispensavel em qualquer paiz civilisado, onde (CONTINUA NOUTRO LOCAL) 